\title{
One Step at a Time... A Tribute to William J. (Bill) Cody, 1922-2009
}

\author{
Paul M. Catling ${ }^{1}$, Bruce BennetT ${ }^{2}$, Gisèle Mitrow ${ }^{1}$, Francis R. CooK $^{3}$, and Jacques Cayouette ${ }^{1}$ \\ ${ }^{1}$ Agriculture and Agri-Food Canada, Environmental Health, Biodiversity, Saunders Building, Central Experimental Farm, \\ Ottawa, Ontario K1A 0C6 Canada; catlingp@agr.gc.ca \\ ${ }^{2}$ Department of Environment, Government of Yukon, Box 2703, Whitehorse, Yukon Y1A 2C6 Canada; e-mail: Bruce.Bennett \\ @gov.yk.ca \\ ${ }^{3}$ R.R. 3, North Augusta, Ontario K0G 1R0 Canada
}

Catling, Paul M., Bruce Bennett, Gisèle Mitrow, Francis R. Cook, and Jacques Cayouette. 2010. One step at a time... a tribute to William J. (Bill) Cody, 1922-2009. Canadian Field-Naturalist 124(1): 71-96.

It is a typical day at the herbarium on the Central Experimental Farm in Ottawa in the spring of 2008 and Bill is coming in the front door of the Saunders Building. "How are you feeling today, Bill?" "One step at a time," he would say. He was tired after coming in for 62 years, but he never said so. He always just said, "one step at a time." In fact, Bill was always optimistic, and he was always ready with a joke or a few words of a song.

He was a dedicated and famous botanist and a very enthusiastic team member. Bill made the world a better place, and it was a very sad day when he passed away on Monday, 23 March 2009, following a stroke. Bill (Figure 1) actually retired from his job with Agriculture and Agri-Food Canada (AAFC) in 1987 at 65 after 41 years of service, but he continued to come in and work every day as an honorary research associate until 2006, and then he came in twice a week until the spring of 2008, a total of 21 years of retirement service.

Bill is widely known for his botanical work in the north and as curator of the largest collection of dried plants in Canada, and as Business Manager of The Canadian Field-Naturalist for nearly 60 years. Many have heard his name in connection with the awards that he earned. These include Honorary Member of the Ottawa Field-Naturalist Club in 1979, the prestigious Canadian Botanical Association Lawson Medal in 1997, a Queen's Golden Jubilee Commemorative Medal in 2002, the Yukon Biodiversity Awareness Award in 2006, the Richards Education Award, a Distinguished Technical Communications Award, an honorary doctoral degree from McMaster University, and various service awards. For many years into the future, people will want to know more about Bill and to trace his work. Here we have encapsulated a lifetime in several pages. Bill's story is a very interesting one that relates to major historical events and important times in Canada, but it is also informative and inspiring because it demonstrates how a single person can make a huge difference.

There are three lists of references at the end of this document. The first is the Literature Cited, where Bill is not an author. The second list is of Bill's research publications (Appendix 1). Where any of these are cited in the text, their appearance is indicated by an asterisk (*). The third list includes Bill's miscellaneous publications (Appendix 2). Few of these are cited but where they are, they are followed by two asterisks $(* *)$. Over the years and after his death, a number of articles (all in the Literature Cited) were written about Bill, including Taylor (1969), Anonymous (1980), Cook (1987), Catling (1991), Pope (1997), Darbyshire (1998), Darbyshire and Taylor (1999), Anonymous (2003), Catling (2003), Anonymous (2004a,b), Benner (2005), Anonymous (2007, 2008), Bennett and Catling (2009), Catling (2009), Catling et al. (2009a), Cayouette (2009), McLachlan Hamilton (2010), Pope (2010) and Cook (2010).

\section{The early days}

Bill was born in Hamilton on 2 December 1922. His father, William Macpherson Cody, was a doctor, actually the first appointed anaesthetist at Hamilton General Hospital. His mother Ola (Ola May Beatty) was a nurse at the same hospital. Bill grew up in Hamilton, in a house opposite Gage Park, and he later lived on Wentworth Street. He loved it, and he loved the Niagara Peninsula, where he worked as a young man on a fruit farm owned by his uncle Bruce near St. Davids. He made his first botanical collections in this region.

Bill attended McMaster University. Botany professor Dr. Lulu Odell Gaiser was responsible for Bill's developing a love of botany. He received his B.A. from McMaster University in 1946 and joined what is now the AAFC the same year after working during the summer as a land use soil surveyor in southern Ontario for the Ontario Department of Planning and Development. As well as being Canada's first cytotaxonomist, Gaiser was an exceptional teacher (Moore and Grant 1965). After taking her taxonomy course, Bill helped her to look after her plant collection (which was transferred to the Royal Botanical Gardens after she retired). She suggested to Bill that he send an application for employment to the herbarium of the federal Department of Agriculture in Ottawa. There were two plant taxon- 
omists on staff at the time, Harold Senn (Cody 1997*) and Ray Moore (Cody et al. 1986*), both of them students of Gaiser's and graduates of McMaster. With Gaiser's earlier communications and current recommendation, they already knew a lot about Bill. Naturally he got the job working as assistant to the curator, Harold Senn, and he started work in the herbarium on 1 October 1946.

\section{Bill's wife and family, and a friend and a church}

Bill married Lois Jean Wright (from Shanly, Ontario) in 1950. They had five children, David (wife Eija), Margaret, Leslie (husband Roland Durocher), Douglas (wife Laurie) and Gordon (wife Mandy). His family was always a major focus, and many of Bill's closest friends find inspiration in the way he put his life together. Lois passed away on 18 March 1998 after 47 and a half years of marriage. Bill was also predeceased by his sister, Elizabeth Marion Cody (Guzwell). See page 59 in the 1954 directory of the Cody family (International Cody Family Association) for more details.

Bill's family was proud of his scientific achievements but, much more than that, his family was a great help. Lois worked part-time for The Canadian FieldNaturalist. She also served as treasurer's assistant from 1968 to 1995 and received the 1988 OFNC Service Award. Lois was also a long-time Girl Guide leader and had numerous leadership positions and responsibilities. It is sometimes said that behind every great man is a great woman, and Bill drew much of his inspiration from a great woman who was beside him. No shadow was cast. Bill's children also took interest in his work. Four collected with him in the north, and Leslie compiled indexes for The Canadian FieldNaturalist. With skill in typing and word processing, she also processed many of Bill's publications and correspondence for him, particularly after he retired.

People sometimes called Bill "Buffalo Bill", perhaps because of his association with wild and distant places, but it is not so much of a stretch. Legendary Buffalo Bill Cody (William Frederick Cody, e.g., see Walsh and Salsbury 1928) was a second cousin of Bill's great-grandfather (Bill's second cousin three times removed). The Cody family is well connected. They have a newsletter: The Genealogical and Historical REVIEW of the International Cody Family Association. Forty-two annual volumes of this newsletter have been produced. A reunion is organized somewhere in North America every other year. The 2006 reunion was held in Cody, Wyoming. Bill's ancestry can be traced back to one of the islands between France and England and afterwards to New England (Cody 1954).

Bill Cody was a very reliable friend. He was five years old when he met Robert Noble Edward Haughton, then four, sliding down a veranda railing in Hamilton, and they stayed in constant contact until Bill's death. Robert followed in his father's footsteps, working for the Bell telephone company. Bill's friends included the broad sweep of society. Bill was also a very faithful member of Trinity United Church in Ottawa. Here he served in the choir for decades, and his various science awards were often on display in the church hall.

\section{Working at Agriculture Canada}

Bill began work with the Department of Agriculture (now Agriculture and Agri-Food Canada) as a junior agricultural assistant working with collections curator Harold Senn in 1946. Later he was appointed senior technical officer, became curator in 1959, and in 1967 was promoted to research scientist. This classification was initiated the year before for researchers who had a Ph.D., but Bill's outstanding accomplishments at that time were judged by his colleagues and the science arm of the federal civil service to warrant treatment at the Ph.D. level. Bill was among the first scientists without a Ph.D. in the civil service to have their work so recognized.

\section{Curating}

The Plant Research Institute was created in 1959, and Bill was made curator of the herbarium. He supervised its growth from 370305 to 800000 specimens by 1987 , when Paul Catling assumed the curatorial responsibility. This collection (Figure 2), now numbering 1.5 million specimens, is the largest of its kind in Canada. It is part of an international network allowing plant material to be borrowed, and it serves research, especially taxonomic research, worldwide. It has become a major tool of AAFC in the identification of economically important plants in connection with the management of invasive plants and enforcement of federal regulations. It also serves as a place where vouchers of material used in scientific studies are preserved. Many thousands of specimens that Bill collected in the northern wilderness under extreme and dangerous conditions are part of this collection, and they serve as vouchers for his numerous publications and books. These specimens have been used in hundreds of plant classification studies.

Bill's job as curator for 29 years included supervising the staff that prepared the material (labelling, mounting, inserting), preparing a budget to obtain supplies, keeping records (Figure 3), responding to requests for loans and information, managing the exchange program (Figure 4), explaining the operation and value of the collection to upper management, making sure that specimens were correctly filed, and assisting visitors. Bill continued to assist with all of these curatorial tasks for 20 years after he stepped down as curator. This was an enormous help at a time when staffing decreased even as the collection was increasing in size and as use of the collection increased. The certificate of appreciation that Bill received each year as an honorary research associate was an embar- 


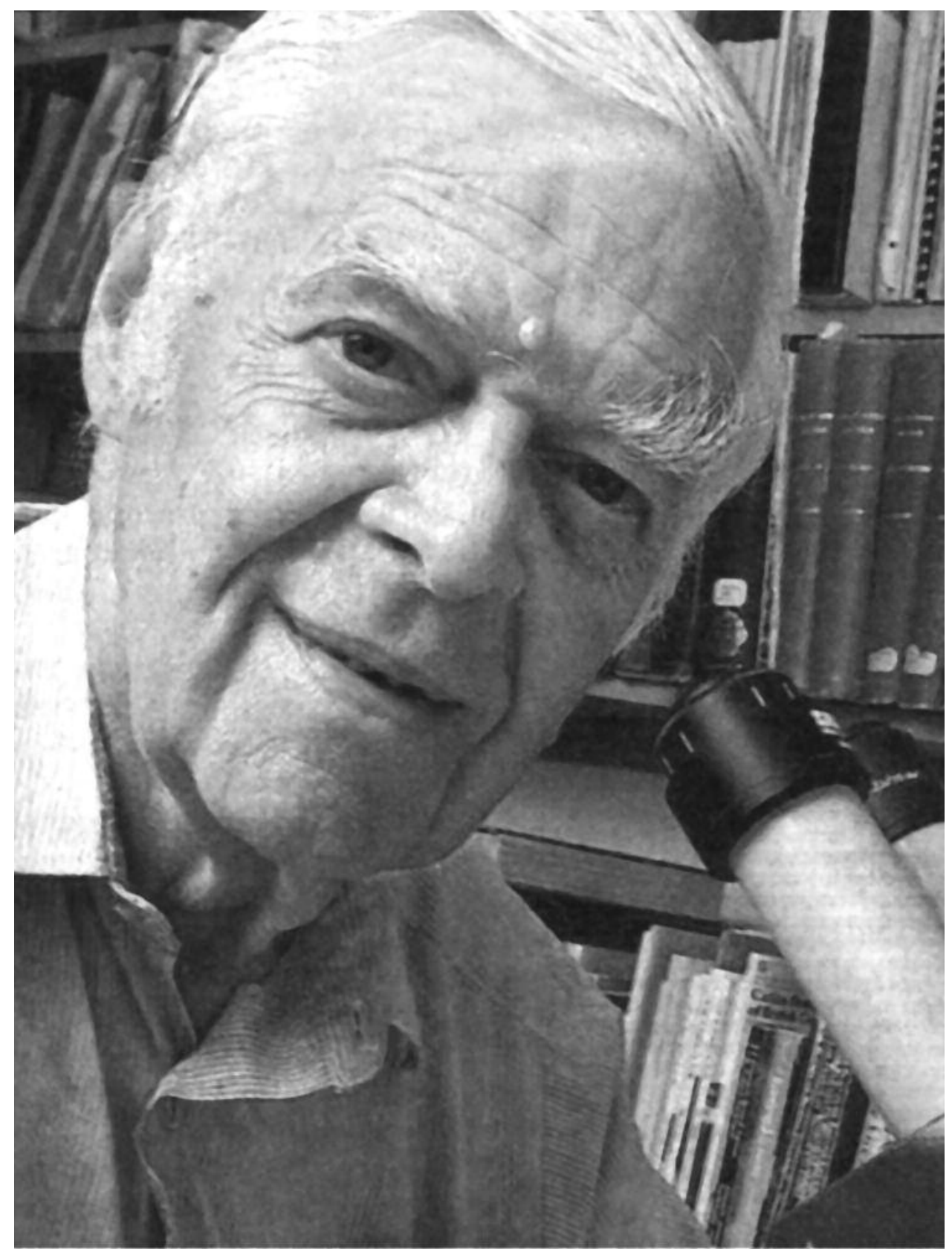

FIgure 1. Bill Cody at his microscope. Photo taken in the Saunders Building, Central Experimental Farm, ca. 2000. Photographer unknown.

rassingly small token of thanks for his huge curatorial contribution. A good curator has a strong and unselfish dedication to a collection, and this can be a rare commodity in a competitive research centre, where ego seeks the recognition that comes with research results.
As well as contributing more than anyone else to the general development of the collection, Bill was instrumental in a number of very important and major improvements. For example, when forcing specimens into the limited space threatened to damage them, 
Bill played a key role in 1986 in the development of a space-saving automatic compactor system that made substantial new space available and reduced costs (Cody 1986b*; Parmelee and Cody 1986*; Barr et al. $\left.1987^{*}\right)$. It was a model system at the time and one of the first in Canada.

In 1992, Bill assisted with the development of a climate control system that was installed to maintain temperature and humidity levels that prevent insect pests from consuming preserved plant material. This avoids the health hazards associated with periodic fumigations using poisonous chemicals. The herbarium was one of the first in Canada to adopt a climate control system to protect specimens and ensure the safety of staff by making chemical fumigation unnecessary.

The herbarium has been a general public focus of scientific activity on the Central Experimental Farm and has had many thousands of visitors. More importantly, it has developed into an extremely valuable tool of research and a service with hundreds of clients and users each year. More than anyone else, we have Bill Cody to thank for this. For more information on the collection, see Catling and Dang (1992) and Catling et al. (2009b).

\section{Publications overview}

Bill's first peer-reviewed paper was published in 1950 in The Canadian Field-Naturalist, and he went on to produce a total of 145 peer-reviewed journal articles and books and 16 reports (Appendix 1). Among his larger contributions are Ferns of the Ottawa District (Cody 1956*, revised Cody 1978a*, issued in French in 1980*), Vascular Plants of Continental Northwest Territories (Porsild and Cody 1980*), Plants of Riding Mountain National Park, Manitoba (Cody 1988b*, both English and French versions), Ferns and Fern allies of Canada (Cody and Britton 1989*, both English and French versions), Systematics in Agriculture Canada at Ottawa 1886-1986 (Cody et al. 1986*), and Flora of the Yukon Territory (Cody 1996*, revised Cody 2000*). These books and the journal articles had a major impact. They are described in detail below under major headings "the North" (including floristic work in Yukon and the Northwest Territories) and "the South" (including work on ferns, parks inventories, and southern Ontario phytogeography). In his various publications, Bill named 16 taxa and made 30 taxonomic transfers (Appendix 3).

Bill's publications reflect the changing trends in systematic botany. During the 1960s and 1970s, when chromosome numbers were important in establishing groups and relationships and the Plant Research Institute was playing a key role, Bill cooperatively produced nine articles reporting chromosome numbers. Bill's reports include some valuable compilations. His production of the catalogue of 4500 type specimens in the National Vascular Plant Collection [DAO: Department of Agriculture Ottawa] (Cody 1996c*) is

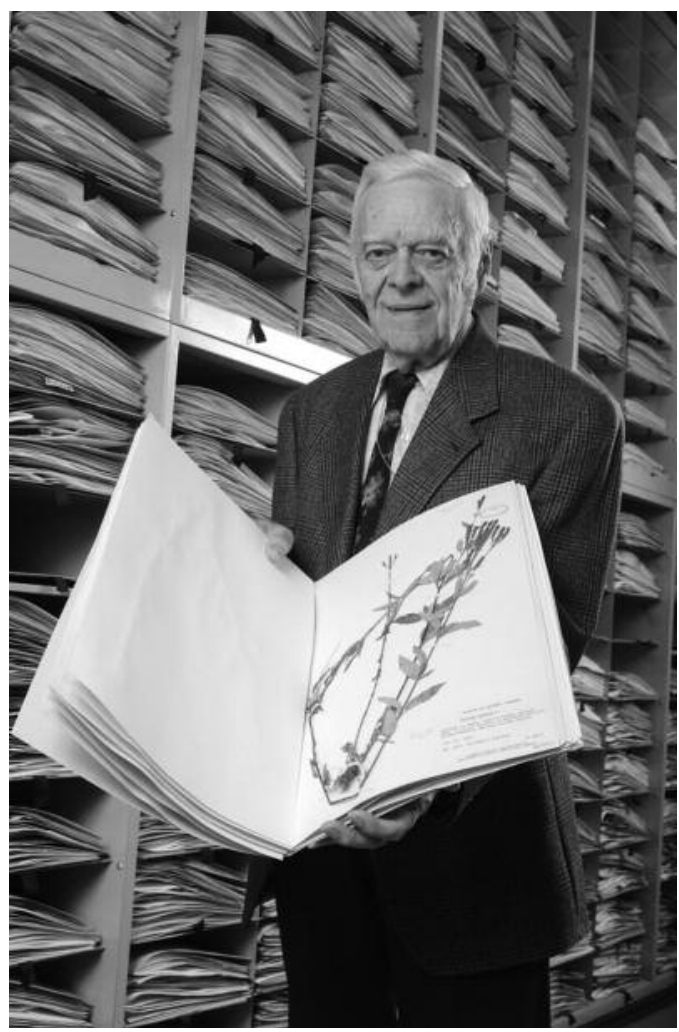

FIGURE 2. Bill Cody demonstrating a plant specimen in the Agriculture and Agri-Food Canada National Collection of Vascular Plants that he was largely instrumental in developing. Photo taken in the Saunders Building, Central Experimental Farm, ca. 2000. Photographer unknown.

particularly valuable and has been extensively used by plant taxonomists worldwide. Bill edited Gillett's index to The Canadian Field-Naturalist and its predecessors (Gillett 1980). This greatly facilitated recovery of information from older volumes. Bill's reports and other publications also contributed much to conservation. He helped with descriptions of important sites in the north for the International Biological Program and he proposed ecological reserves (Simmons and Cody 1974*). The information that he provided on rare plants (Cody 1979*; McJannet et al. 1995*) has contributed to their conservation.

Bill reviewed many hundreds of manuscripts for journal editors and colleagues. This is not unusual for a scientist, but there was something special about the way Bill did it. He always stopped his own work and gave the review priority. He was the person that you could take something to and say, "I need a review of this in an hour," and you would have it back in 30 minutes. He also reviewed chapters for the multi-volume Flora of North America project developed by the Missouri Botanical Garden. 


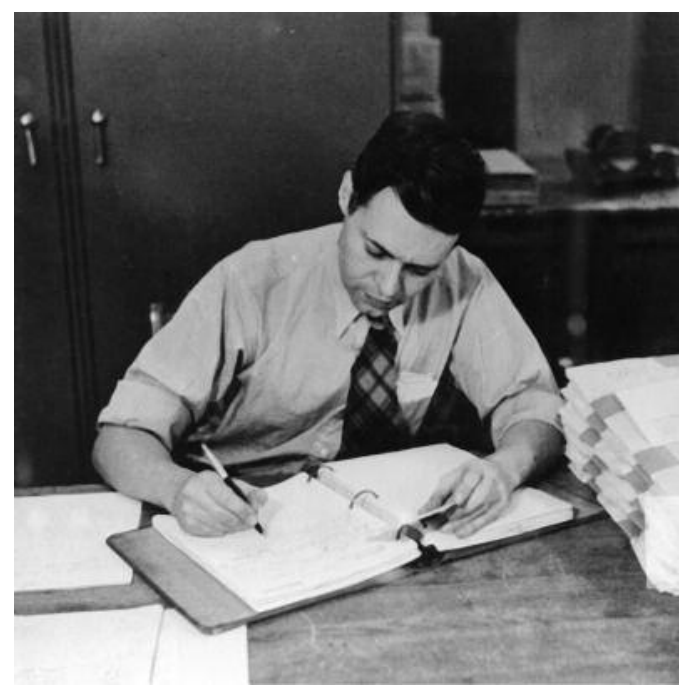

FIGURE 3. Bill Cody keeping herbarium records in the 1960s. This photo was likely taken in the Botany Building. The herbarium was moved to the Saunders Building in 1969. Photographer unknown.

Bill produced 180 miscellaneous publications (Appendix 2), including 154 non-refereed book reviews), 11 seed lists, and 15 encyclopaedia contributions. Most of the books reviewed were identification guides to the plants of different regions. They covered various provinces, states, or regions of Canada, the United States, and countries in Europe. They included floristic lists; regional rare plant contributions; lists of common names; vegetation studies; books or publications on ferns, trees, shrubs; various monographs on plants; botanical exploration; and history. These reviews were very helpful in drawing attention to new information that had become available in the days before information could be searched for on the Web.

The seed lists (Index Seminum) were produced from 1963 to 1973 . After the 1950 s, it was customary for botanical institutions to gather seeds and produce lists of the species for which seeds were available. Seeds were available to anyone who requested them. Research centres and botanical gardens around the world exchanged lists and obtained plants for research and horticulture. The lists that Bill coordinated and produced on behalf of the Department of Agriculture included hundreds of species and were $20-30$ pages in length. They were a significant contribution, enabling Canada to participate in the national network. Important material of crop plants for research was obtained this way. Some of the unusual trees in the Dominion Arboretum on the Central Experimental Farm can be traced back to the days of the seed exchange.

Most of Bill's journal articles were published here in The Canadian Field-Naturalist, including 81 and
726 pages (with his final Yukon contribution in this issue), almost certainly setting a record. He also published a number of articles in the Canadian Journal of Botany, Le Naturaliste canadien, Rhodora, and Taxon, and a smaller number in numerous other journals and bulletins, including the American Fern Journal, the Bulletin of the Torrey Botanical Club, the Blue Jay, Phytochemistry, the Canadian Journal of Plant Science, the Canadian Botanical Association Bulletin, Syllogeus, the Plant Press, Park News Magazine, Quatre-Temps, Herbarium News, Madroño, and Trail \& Landscape.

Much of Bill's work was done prior to the 1980s, before computers and word processing, when writing took longer. He had an Underwood typewriter with its ink ribbon as well as a bottle of white correction fluid, and he used both for some of his work until 2007. He also shared the typewriter with others when the modern equipment broke down but never touched the computer some well-meaning colleagues eventually had placed in his office. He willingly had staff and Leslie (after he had retired) enter his manuscripts on their computers as electronic methods became more popular.

Bill had an interest in remembering and honouring his co-workers. He wrote six tributes to botanists he had worked with: Ralph Anthony Ludwig (Cody 1977*), Alf Erling Porsild (Soper and Cody 1978a,b*; Cody 1985g**), Bernard Boivin (Cody 1985*; Cody and Cayouette 1986*; Cayouette and Cody 1989*), James Alexander Calder (Cody and Cayouette 1991*), Harold Archie Senn (Cody 1997*), and Hugh Miller Raup (Cody 1998a*). All this, as well as his review of systematics in Agriculture Canada (Cody et al. 1986*), represents a valuable contribution to botanical history in Canada.

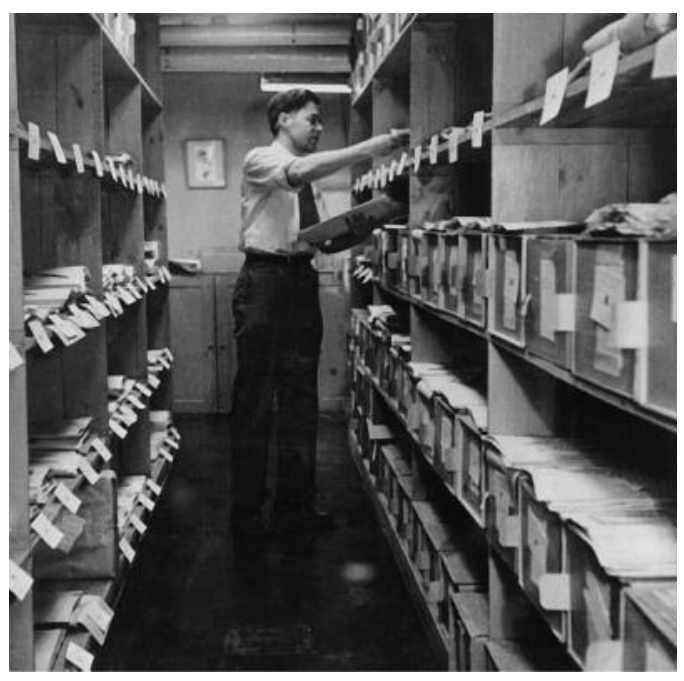

FIGURE 4. Bill Cody sorting exchanges. Photo taken in the Saunders Building during the 1960s at the Central Experimental Farm. Photographer unknown. 


\section{Collections and identifications}

Bill's earliest collections were made while he was a student at McMaster University, prior to 1946. These collections were from the Niagara Peninsula near St. Davids, from the Niagara Escarpment above Hamilton, and from Stoney Creek. They are preserved in the herbarium of the Royal Botanical Gardens in Hamilton. All of Bill's later collections are in the National Vascular Plant Collection of Agriculture and Agri-Food Canada (international collection acronym: DAO).

Over the period of his life, Bill collected approximately 40000 specimens. It is estimated that at least 30000 of these resulted from his 17 expeditions to the north (see below). The remaining 10000 specimens are from southern Canada and especially from Ontario and Manitoba in connection with floristic inventories of Riding Mountain National Park in Manitoba (Cody 1988b*) and St. Lawrence Islands National Park in Ontario (Cody 1975b*, 1978b*; McNeill and Cody 1978*; Boivin 1980). Label data for some of his collections are available online; for example, 71 specimens collected by Bill are listed in the online catalogue of 4500 type specimens (Catling et al. 2009b). Other specimens collected by Bill will be available as images in a virtual herbarium of the Northwest Territories that may soon be available online.

Many people assisted Bill in collecting, and these major collaborators are listed elsewhere. An easily overlooked group of associate collectors was his family. Bill was very dedicated to improving the plant collection and no family expedition was a success without an addition to it.

Bill often collected duplicates for exchange with other research centres, and these have been distributed around the world. Exchanges may have brought as many as 200000 specimens in to DAO, and they contributed greatly to its development as the best collection representing all of Canada. Through exchanges the herbarium became an outstanding collection representing the temperate regions of the world and has an especially good collection of weeds, crops, and crop relatives. Through his duplicates, W. J. Cody is listed as one of the important contributors to the herbarium of the Institut botanique de l'Université de Montréal, now the Herbier Marie-Victorin at the Institut de recherche en biologie végétale (MT) (Boivin 1980).

One of Bill's larger post-retirement contributions was the identification of many thousands of specimens. Each year he provided an enormous amount of information on plants to the agricultural sector, natural resources staff, wildlife biologists, native people and landscape planners as a contribution to the AAFC Vascular Plant National Identification Service.

\section{The north}

Bill's contribution to Canada and botanical research was enormous, and much of it had to do with the Cana- dian north. Both to honour Bill and to assist students of Canadian botany, his northern legacy has been outlined along with a list of his 73 scientific publications concerning the Northwest Territories, Nunavut and Yukon (Bennett and Catling 2009). The following text is mostly derived from that source. For most of the period of Bill's work in the north, Nunavut had not yet been established and much of the information about that territory is therefore included under "Northwest Territories."

\section{Before Bill}

In 1948, the most important and extensive collections made in the continental Northwest Territories were still those that had been made by surgeon-naturalist Sir John Richardson between the years 1819 and 1827 as part of Sir John Franklin's first and second expeditions to the Arctic to find the Northwest Passage (Pringle 1995). In all, Richardson collected 474 species of flowering plants and ferns that later appeared in W. J. Hooker's classic Flora Boreali-Americana. This was a third of the species known today.

Prior to the middle of the 20th century, comprehensive information on the flora of the Yukon and continental Northwest Territories was just emerging, mainly from outside the country. It included Nicholas Polunin's Botany of the Canadian eastern Arctic (1940) as well as J. P. Anderson's papers on the flora of Alaska and adjacent parts of Canada (1943-1950) and Eric Hultén's Flora of Alaska and Yukon (1941-1950 and published with brief descriptions, maps and keys in 1968). Alf Erling Porsild had written several works, including Materials for a flora of the continental Northwest Territories of Canada (1943) and Alpine flora of the east slope of Mackenzie Mountains, Northwest Territories (1945). A major contribution was Raup's Botany of southwestern Mackenzie (1947).

Although some of the collections were made by specialized botanists focused on making a complete regional inventory, most of the early plant collections were made opportunistically by explorers, geologists, missionaries, and general naturalists (Pringle 1995). Apart from the Mackenzie Mountains, which were explored as a consequence of the development of the Canol Road, and Raup's work, there had been very little comprehensive botanical exploration of northwestern Canada at this time (for useful reviews, see Porsild (1943), Porsild and Cody (1980*) and Cody (2000a*)). Despite having been included in regional floras, the plants of northwestern Canada were still not well known.

\section{The time was right}

Quite often good science is carried on the crest of a political and/or economic wave, and this was true in the middle and later 20th century, when two events resulted in great attention to Canada's northern sovereignty. These were the development of the oil and gas industry in the north and the concern over attack 
across the North Pole. It was a period of conflict, tension, and competition with the Soviet Union. During this time the Distant Early Warning Line (DEW line), a series of radar stations, was established across the north to detect incoming Soviet bombers. Defence Research Board, Department of National Defence, cooperatively with the federal Department of Agriculture, undertook a major survey of biting insects in 1947 (Freeman 1954, 1959), because biting insects are so abundant at certain times in the north that human activity is severely restricted. These insect studies required the involvement of botanists to describe the habitat, and this was the basis for Bill Cody's first trip to the north, in 1948. The insect research also supported several other botanical surveys by expert botanists, such as James A. Calder's survey around Dawson in 1949 (Cody and Cayouette 1991*) and John M. Gillett's surveys near Watson Lake and Whitehorse the same year. The botanical results of the northern insect survey project were included in a series of reports by the Defence Research Board (e.g., Freeman 1948; Cody 1949*).

Development in the north required a better understanding of natural resources. With the proposal for a Mackenzie valley gas pipeline, activities, including plant inventories, increased dramatically in the Northwest Territories, particularly in the vicinity of the Mackenzie River. The Canadian Wildlife Service (now part of Environment Canada) sponsored numerous studies to provide information for landscape planning in connection with protection of wildlife, and Bill was invited to provide botanical information. Between 1964 and 1974, the International Biological Program was a major force. It sought to identify critical natural areas and to apply current methodologies to ecosystem ecology on a global scale. Large advances in knowledge of the north resulted from this program, and Bill contributed extensively. For example, he produced a comprehensive report (Simmons and Cody 1974*) proposing ecological reserves in the Northwest Territories (Plains of Abraham, Brackett Lake, Glacier Lake, and Pilot Lake). The economic as well as strategic benefits of a presence in the north were well understood. Funding to support this development became widely available, and travel in the north suddenly became a lot easier. For example, Bill was able to take advantage of the Polar Continental Shelf Program of Natural Resources Canada, which provided well-organized and efficient transport to remote areas by small airplane and helicopter.

\section{Expeditions to the north}

To write books about plants in the north, Bill had to know what was there. The work of other botanists was useful but not enough for a comprehensive text. This meant that Bill had to travel throughout the northern wilderness, enduring severe weather, hordes of biting insects, risks of bear attack, and the dangers inherent in wilderness travel by bush plane and helicopter.

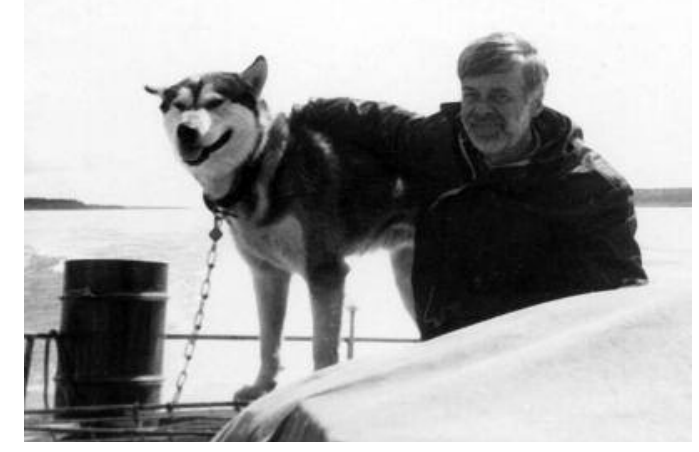

FIgURE 5. Bill Cody and a dog. Photo likely taken on the Keele River in the lower Mackenzie River valley in 1970. Photographer unknown.

Unlike some, however, Bill was a good fit with the north (Figure 5), and he responded well to what Robert Service called the "Law of the Yukon." The federal Department of Agriculture approved and encouraged Bill's travels, and during his frequent periods of absence his devoted wife Lois cared for their family.

Bill began his work in the north in 1948, collecting specimens at Coral Harbour, Southampton Island, at the north end of Hudson Bay. This and additional expeditions up to 1951 were undertaken as part of the study of biting flies and their habitats for the Defence Research Board. His first visit to the continental Northwest Territories was in 1949, when Bill, accompanied by J. B. McCanse, collected around Yellowknife, the Snare River, eastern Great Bear Lake, and Norman Wells. In 1950, accompanied by C. C. Loan, he collected at Fort Smith, where he studied the salt plains a few miles west of town. In 1951, he collected in central Alaska along the Richardson Highway near Delta Junction with T. J. M. Webster. His field books (now part of the DAO archive) for this Alaska trip indicate that he was there to assist in ecological studies of biting flies, especially mosquito breeding habitats, but as usual he collected extensively and acquired a large amount of information not directly related to the insect studies but essential to our understanding of northern botany.

He did not travel north in 1952, but 1953 saw him collecting in Lac La Biche, northern Alberta, and with R. L. Gutteridge in the vicinity of Norman Wells, the Canol Road, and Aklavik in the Northwest Territories. Bill remained in Ottawa in 1954 and did very little fieldwork. In 1955, he was making collections with J. M. Matte in Fort Simpson. These collections were particularly significant, as many were the first reports of species that are now known to be invasive in the region. He was unable to travel north in 1956, but in 1957 he collected with D. H. Ferguson around Reindeer Station 
on the east side of the Mackenzie River delta. From 1958 to 1960 he did not travel north, but in 1961 he worked with K. W. Spicer for the federal Department of Agriculture with a soil survey party along the Liard River from the British Columbia border to the junction with the Mackenzie River at Fort Simpson. In 1962, he was not in the north, but in 1963 he was collecting again at Reindeer Station, as well as on the east slope of the Richardson Mountains to try to determine the effects of grazing by introduced reindeer on the local habitats. In 1964, he was not in the north but in 1965 he collected along the Slave River between Fort Smith and Great Slave Lake, including Hay River. It was in 1965 that he and Erling Porsild of the National Museum of Canada (now the Canadian Museum of Nature) began writing Vascular Plants of Continental Northwest Territories. In 1966, Bill was again in the southern Northwest Territories.

In 1967, along with K. W. Spicer, he collected in the Mackenzie Mountains with a field party from the Geological Survey of Canada and in the southern part of Yukon along the newly constructed Robert Campbell Highway and Nahanni Range Road. This was his first time collecting in Yukon. Bill was absent from the north in 1968 and 1969. In 1970-1972, he took part in field studies in the Mackenzie Mountains and various other localities in the southern Mackenzie District to assess sites that had been recommended for preservation in the International Biological Program/Conservation of Terrestrial Habitats project. He was on the Keele River in 1970 when he barely escaped a severe flood of his riverside camp (see below). Bill did not go north again until 1980, when he travelled extensively in Yukon collecting throughout southern Yukon from Watson Lake along the Alaska Highway, through Carcross and Tagish, Whitehorse, Kluane Lake, Haines Junction, the Haines Road, the Canol Road, Ross River, Carmacks, then up the Dempster Highway to Inuvik. He then began a reconnaissance in the area, which was then known as "the Northern Yukon National Park study area." Helicopter support was provided by the Polar Continental Shelf Program. This area included the British Mountains and the Yukon North Slope. Sites visited in this first significant Yukon trip included the Clarence Lagoon, Stokes Point, the Firth River, the Malcolm River, Roland Creek, Spring Creek, Empire Mountain, and Komakuk Beach. He continued retracing the Dempster Highway and the Klondike Highway, the Nisling River and on to Haines Junction and throughout the Front Ranges of Kluane National Park, including Kathleen Lake, the Alsek River, the Slims River, and Mount Decoli. He then travelled through Whitehorse again to Ross River via the South Canol Road, back to the Klondike Highway to Dawson City, and once more onto the Dempster in what is now Tombstone Park.

In 1981, he collected in the vicinity of Fort Liard in the Northwest Territories and on the South Canol Road in Yukon. He worked in the Macmillan Pass for several weeks, and for the first time he was invited to cooperate with the Government of Yukon as an expert on the region. It was at this time that he met Catherine Kennedy, who remained a friend and colleague. As well as collecting in southern Yukon in 1982, Bill collected throughout the Richardson Mountains, where, with helicopter support provided by funding from the Polar Continental Shelf Program and with the help of mycologist James H. Ginns, he collected nearly 2500 specimens. In 1983, he once again teamed up with Catherine Kennedy and collected in the southeastern corner of Yukon, including some significant sites near and including Coal River Springs and along the Alaska Highway. In 1984, he returned with J. H. Ginns and, with helicopter support, collected throughout the Ogilvie and Wernecke mountains, in the Dawson City area (including West Dawson), and downstream on the Yukon River to the Alaska border. He once again amassed an amazing number of collections in excess of 2500. It was mainly through the collections of 1980-1984 that he was able to begin compiling his final great botanical work, Flora of the Yukon Territory, which was published in 1996.

Although 1984 was his last official scientific expedition to the north, Bill was to make four more familyrelated trips. Beginning in 1999, he took four of his children, one by one, to see the Yukon by travelling Yukon's southern highways. He took Gordon in 1999 and once again travelled the southwest Yukon before travelling north up the Dempster Highway and assisting Catherine Kennedy with research on Herschel Island. In 2000, with his son David doing most of the driving, he travelled over $4500 \mathrm{~km}$ of roads in the central and western part of Yukon from the Alaska border west of Dawson and Beaver Creek to the British Columbia boundary on the Haines Road and Klondike Highway and along most of the Canol Road. They collected a total of over 500 sheets of specimens from 156 locations, making significant collections of introduced species along the roadsides. This was a remarkable distance to cover and a substantial collection quite an achievement for a three-week trip, sometimes on dangerous roads. In 2001, Bill returned with his daughter Margaret, travelling the highways and byways of central Yukon, again collecting hundreds of plants and travelling over an extensive area and camping in the wilderness (Figure 9). Finally, in 2002, Bill returned for his final visit to southern Yukon with his son Douglas. Not surprisingly, this trip also resulted in a good number of plant collections.

\section{A flood on the Keele River}

Wilderness travel is dangerous. Help can be thousands of miles away. While knowledge, experience, and common sense provide some protection, events often cannot be predicted or controlled. So it was in the log cabin (Figures 6 and 7) beside the Keele River in the lower Mackenzie River valley on 20 July 1970. 


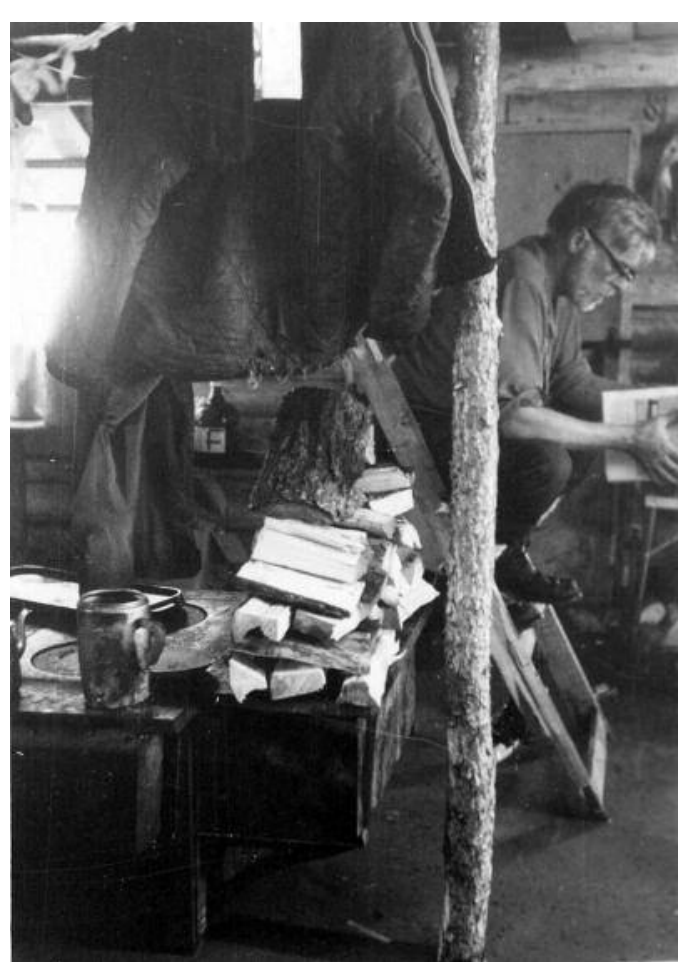

FIGURE 6. Bill sitting reading on the ladder to the attic. A bottle of Fisher alcohol can be seen under the coat, and split wood is piled on the edge of the wood stove. This was rough accommodation, but much of Bill's time in the north was spent in tents drying plant specimens in presses over an open fire. Keele River, Northwest Territories, 1970. Photographer unknown.

Nine people occupied a log cabin and canvas wall tents on the forested shore of the Keele River. The group included skilled Mountain Dene, Uncle Gabe (Gabriel Etchinelle, who had spent much time there); a bush plane pilot and jet boat driver named Perry Linton; "Wild Bill Cody and his plant presses"; John Day, who was a soil specialist; Norman Simmons (Simmons and Cody 1994*), and Harry Armbruster of the Canadian Wildlife Service, who were studying Dall's sheep and caribou; and Hilah Simmons with seven-year-old Debby and five-year-old David.

The usual preparations for the day's work - collecting plant and soil specimens, tree measurements, aerial sheep surveys - suddenly gave way to surprise as heavy rains began. Within minutes, the river began to flow faster, rose and turned brown. A few minutes later whole trees ripped away from the bank and were carried downstream in the current. There was no time to waste. The boat was secured and two of the men set off to the airstrip a mile downriver to secure the plane. They were not able to reach it because the woodland

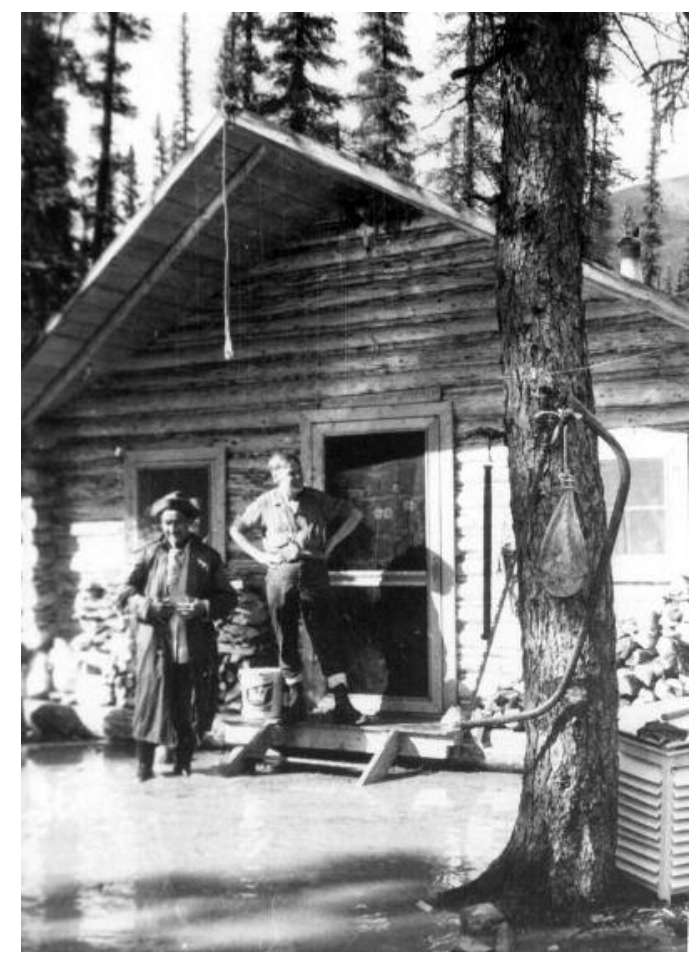

FIGURE 7. Bill Cody (right) and Dene Gabe (left, standing in floodwater) at the log cabin as floodwaters rose to the front door. The water eventually rose to at least the level of Bill's waist. Keele River, Northwest Territories, 1970. Photographer unknown.

camp was now surrounded by rising water channels, so they set out again in an inflatable boat. At the camp, fuel was moved to the highest ground, the dock was moved up the bank, the tents were brought into the cabin, and material was suspended from trees. The water began to come into the cabin. First bags and then blankets were moved to the upper bunks. Water was soon knee high in the cabin. The kids, dry clothes, food, and blankets were moved to the attic. The malamutes, with no place to go, were barely recovered through an open window as the current rushed by.

Amidst shouts of panic drowned out by the sound of rushing water, a discussion commenced. Should they stay in the cabin or get into the boat? Where were the others who had gone to the airstrip? The brown river roared against the cabin as waves carried debris past. Nearby trees had gone. It was too late to get in the boat; both boat and dock were gone. Water rose over the table and stove, where the dogs perched, looking for a higher shelf. Nothing was said. Hours passed with nothing but the sound of rushing water, pelting rain, 
and walls groaning against the sheer pressure of the water. Would they be swept away? Now it was just a matter of waiting. How much more could the water rise before the lower logs became buoyant and rose, making the cabin fall? The cabin creaked and groaned, and all lay snug and silent for a long time.

Gradually the rains stopped. One day became another, and the water went down. Piles of wet sand, puddles, and debris surrounded the camp, and river channels were still high and fast. A radio antenna was affixed to a tree, and a mayday signal was sent to Fort Liard. The helicopter finally arrived and was dispatched to the airfield. The plane rescue was unsuccessful (the plane had disappeared), but the two rescuers were on a tiny platform built in the nearby trees, where they had been for almost 24 hours. Everyone made it. The jet boat was extricated from the treetops and pushed back to the river across the snye (side channel) before the water level fully subsided. A new base camp had to be set up until the runway was drained and cleared. Yes, Bill's plant specimens survived, dry and safe in the attic.

The preceding story is as told by Bill, but it also appeared on pages 24 and 25 of the January 2001 issue of a local newspaper, the Mackenzie Valley Viewer.

\section{Post-expedition period, 1985-2008}

This period of compiling information, identifying thousands of specimens, and preparing current identification keys required special skills. These skills are quite different from those needed for northern travel. Hard and diligent work was essential, but Bill's interest in working with people also played a major role. This period was probably just as important to Bill's achievement as the expeditions in the north. It included major follow-up research contributions and, because he enlisted the help of others, knowledge of and responsibility for information on northern flora were greatly expanded during this period.

While Bill's early work in the north often utilized material collected by others, there were few, other than Alf Erling Porsild (see Soper and Cody 1978a,b*), with a deep interest in northern plants. That changed after the Porsild and Cody (1980*) flora, which enabled more people to be involved. Most major contributions involve more than one person, and Bill's work was no exception. He had help from a number of legendary northern botanists, including G. W. Argus, B. A. Bennett, P. Caswell, Catherine Kennedy, K. L. MacInnes, K. L. Reading, R. Rosie, G. W. Scotter, and S. C. Zoltai. Other people also helped, including his daughter Leslie in particular, who typed or input his manuscripts. Bill was a very pleasant and dependable person to work with and there can be little doubt that this helped him to achieve as much as he did.

\section{The essence of Bill's achievement in the north}

For many northern species, there were only a few records half a century ago. Bill dramatically changed that by finding many hundreds of plants in new areas and noting their habitats. Our knowledge of the occurrence and ecology of northern plants expanded enormously by 2008. Of course, this vast increase in knowledge is also reflected in the number of taxa known. For example, in 1943 Porsild reported 731 taxa (species and infrataxa) from the Northwest Territories. The flora of the Northwest Territories is now known to contain over 1254 species alone (not including infrataxa: Catling et al. 2008), roughly double the number reported by Porsild, and much of this is attributable to Bill's work. The same is true for Yukon, where Bill added 208 taxa. Although our knowledge of the northern flora may still not be entirely satisfactory, it is vastly improved over what it was.

Since Bill always wanted to be complete in his botanical documentation, he searched for and collected introduced plants. His work in documenting invasive plants provided a baseline for evaluating their spread. Many of the earliest reports of introduced and naturalized species in the Mackenzie River valley are based on Bill's early collections. He produced the first two focused and comprehensive articles on invasive plants in the north, featuring Wood Buffalo National Park (Wein et al. 1992*) and the Norman Wells pipeline (Cody et al. 2000b*). As well as his work in Wood Buffalo National Park (which helped to provide a basis for management of natural resources), Bill published on the flora of other northern protected areas, including Nahanni National Park Reserve (Scotter and Cody 1974*; Cody et al. 1979*), Bylot Island (part of Sirmilik National Park, Cody et al. 1984b*), and Bathurst Inlet (Cody 1954a*; Cody et al. 1984a*).

Most of Bill's collections, actually $75 \%$, were the result of his 17 expeditions to the north, with perhaps a few thousand more from Yukon than from the Northwest Territories and Nunavut. Throughout the period and subsequently, it is estimated that he processed as many as 20000 specimens collected by others; over $80 \%$ of these were from north of the 60th parallel. Always happy to answer questions, he responded to many hundreds of requests for information and identifications each year. Bill made his botanical knowledge of the north available in two books and 71 publications, most of them peer-reviewed.

Bill Cody's work in the north is essential, not only as a basis for the protection of plant biodiversity and for the establishment of protected areas, but also for biological research and ongoing work relating to ecology, forestry, sustainable resource management, and wildlife management. The importance of his work in the north went sometimes beyond that area and covers phytogeographical information relevant to the whole of Canada. The distribution maps in Porsild and Cody's Vascular Plants of the Continental Northwest Territories are a good example. As they covered the whole Canada and part of adjacent United States, they become very useful information on the range of many plant species as the only North American maps available before the Flora of North America project. It is 
no surprise that northern plants are named after him and that he received major awards for his northern research (see below).

\section{The south}

\section{Ferns and fern allies}

Bill's largest area of contributions outside his work on the north was in the taxonomy and geography of ferns and fern allies. In this area Bill produced 2 books, 20 journal articles (see Appendix 1: Cody 1955*, 1956b*, 1961c*, 1963c*, 1968*, 1969*; Mulligan and Cody 1969*; Mulligan et al. 1972a*; Cody and Crompton 1975*; Cody and Lafontaine 1975*; Cody et al. 1977*; Mulligan and Cody 1979*; Cody and Wagner 1981*; Cody and Mulligan 1982*; Cody 1983a*; Cody and Britton 1984*; Britton et al. 1985*; Cody and Britton 1985*; Cody and Schueler 1988*; Cody and Britton 1989*; Lichvar and Cody 1994*; Cody 2001*) and 3 encyclopedia contributions (see Appendix 2: Cody 1985 d,e,f**). The articles included taxonomic clarifications, such as the name of Polystichum acrostichoides $\times$ lonchitis (Cody 1968*); newly discovered taxa, such as Adiantum pedatum ssp. calderi (Cody 1983a*); reviews of the biology of economically important species, such as Pteridium aquilinum (Cody and Crompton 1975*), Dennstaedtia punctilobula (Cody et al. 1977*), and Equisetum arvense (Cody and Wagner 1981*); and significant range extensions, such as Polystichum lemmonii in British Columbia (Cody and Britton 1984*) and Cystopteris protrusa in Ontario (Britton et al. $\left.1985^{*}\right)$.

Despite its regional nature, Bill's Ferns of the Ottawa District (Cody 1956b*, revised 1978a*) was a very valuable field guide that could be used over an extensive area of the northeast by both naturalists and professional biologists (Desmarais 1957; Britton 1979). It included photographs and keys that facilitated identification. A remarkable number of botanists have used this book to learn about ferns (in 1956, it was only $\$ 1.00)$. For some additional information on this book, see Britton (1979).

Ferns and fern allies of Canada (Cody and Britton 1989*) included a large amount of information, and it brought Bill's earlier work on ferns together. Bill was bogged down in 1983 when the book was scheduled for publication. It was a little outdated because by that time he had been encouraged to turn his attention increasingly to the north. Local fern specialist Dan Brunton had the brilliant idea of inviting another Canadian expert, Don Britton at the University of Guelph (Catling 1991; Brunton 2003), to help finish the job. That made all the difference. Although the content was good (but a little skimpy on discussion of hybrids), the production was poor (binding, layout, maps, etc.) and when published in 1989, it still was obviously an update of the 1983 (or older text) with pre- and post 1983 lists of references and other addenda. These things detracted from its excellent content. One of the better reviews was that of Martin (1990). Although this book was not as well received as Bill's other books, it was considered a very valuable contribution by reviewers (e.g., Barrington 1990) and it did definitely bring knowledge of Canada's fern flora to a much higher level. Considering that Bill was not afforded the same amount of time as other scientists to write due to his extensive curatorial responsibilities, it is a wonder that he was able to complete this work at all.

\section{Phytogeography and floristics}

As well as studying and documenting plant distribution in the north, Bill wrote several articles documenting important patterns of plant distribution in southern Ontario, including occurrences of boreal species (Cody $\left.1962 b^{*}\right)$, a detailed study of plant geography in St. Lawrence Islands National Park (Cody 1975b*), an article relating island size to number of species present in the St. Lawrence islands (McNeill and Cody $\left.1978^{*}\right)$, and a detailed review of the northern limits of plants in eastern Ontario that also developed from his research in the St. Lawrence islands (Cody 1982*). The last paper provided very useful distribution maps that were instrumental in updating the knowledge of the range of the rare plants in eastern Ontario, as well as western and southern Quebec.

Bill's contribution to plant distribution, new records, and range extensions included both native and introduced plants for various parts of Canada. Some of them consider North America, Canada, or large areas as a whole (Cody 1953b*, 1954d*; Cody and Talbot 1973*; Cody 1975a*, 1978c*), while others are of provincial or of local importance: Prince Edward Island (Cody and MacLaren 1976*); New Brunswick (Cody and Munro 1980*); Ontario and Quebec, including James Bay (Cody 1954c*) and the Ottawa District (Cody 1957*, 1967a*); Ontario (Cody 1952*, 1962b*, 1970*; Cody and Boivin 1973*; Cody and Putman 1986*; Staniforth et al. 2002*); Manitoba (Cody and Krivda 1974*; Cody 1980*; Cody and Saquet 1984*); Saskatchewan (Cody 1973*, 1988a*); Alberta (Cody and Shaw 1973*; Cody et al. 1974*; Cody and Scotter 1990*); and British Columbia (Cody 1967b*).

The native genera considered here are remarkably various and indicate Bill's broad knowledge of Canadian vascular plants, including Carex (Cody and Krivda 1974*), Cypripedium (Cody 1973*), Draba (Cody 1957*), Elymus (Cody 1967b*), Listera (Cody and Munro 1980*), Loiseleuria (Cody et al. 1974*), Lythrum (Cody 1978c*), Monotropa (Cody and Saquet 1984*), Phyllodoce (Cody 1953b*), Pinguicula (Cody 1962b*), Prunus (Cody and Shaw 1973*), Rorippa (Mulligan and Cody 1995*), Salicornia (Cody 1954c*), Sarracenia (Cody and Talbot 1973*), Scheuchzeria (Cody 1975a*), Tillaea (Cody 1954d*), and Wolffia (Cody 1980*). As reported above, Bill was always interested in new records of introduced plants, whether adventive, escaped from cultivation, or new weeds, and his papers would present them according to their national or regional impact. The main genera include 
the following: Ceratocephalus (Cody 1988a*), Chrysopsis (Cody 1952*), Crepis (Cody and Putman 1986*), Echinacea (Cody and Boivin 1973*), Geranium (Cody and Scotter 1990*), Iris (Cody 1961b*), Lychnis (Cody and Frankton 1971*), Sedum (Cody 1967a*), Sorbaria (Cody 1962a*), and various others (Cody and MacLaren 1976*).

\section{Botanical inventories of parks}

In the 1970s, the Department of Agriculture (which was where the botanists and entomologists in the federal government were located) assisted with biological inventories of Canadian parks (Catling and Cody 1987*). Bill was responsible for inventories of the vascular plants of St. Lawrence Islands National Park (Cody 1975b*, 1978b*). For this project he contributed, with technician Derek Munro, to the small herbarium of the park (Boivin 1980). Bill was also responsible for the inventory of Riding Mountain National Park (Cody 1988b*). The latter was published as an identification guide. It included 88 plant families, 300 genera, 669 species, and 2 hybrids, with keys that included brief descriptions and line drawings of about half of the flora (Cayouette 1989). All this resulted from surveys done in 1979 and 1983, with the help of technician Walter Wojtas, and examination of previous records in various herbaria. The book contains information such as relationships between tree species and soil and physiographical aspects, an outline of the main plant population ranges, and the major forest and ecological groups of the park. It became a very useful guide to the vascular plant biodiversity in the park and has been extensively used in park planning. Unfortunately, the French version, which could have been very useful for francophones in eastern as well as western Canada, would have benefited from the knowledge and editorship of a francophone botanist. Learning of the problems with the French translation afterward, Bill considered himself the author of the English version but not of the French (Cayouette 1989).

Bill was also instrumental in the botanical exploration of another Canadian park, Kouchibouguac National Park in New Brunswick. He supervised the fieldwork and report of technician Derek Munro, and he helped to produce a list of all the identifications (Munro 1979). One paper on Listera in New Brunswick came out of this important inventory (Cody and Munro 1980*). Several other park inventories that Bill did were of the northern parks, including Nahanni National Park Reserve, Bylot Island (part of Sirmilik National Park), and Bathurst Inlet (see above).

\section{Bill and The Ottawa Field-Naturalists' Club}

Bill made a huge contribution to the biology/conservation organization, The Ottawa Field-Naturalists' Club (OFNC) (Cook 1987); see also Brunton (2004) for a fascinating history of the OFNC. Bill joined the OFNC (founded 1879) when he arrived in Ottawa in 1946. He was appointed assistant treasurer in 1947 and was elected to Council in 1948 and served continuously until 2007.

He was appointed to the newly created post of business manager in 1948. One of his first duties was to organize the extensive holdings of issues of the Canadian Field-Naturalist (formerly the Ottawa Naturalist, 1887-1919, and the Transactions of the Ottawa FieldNaturalists' Club, 1879-1886) and to advertise their availability for sale as sets and single numbers to help support the publication costs of subsequent issues. As well, he assumed responsibility for reprint orders and mailing lists (all of which had been handled by the editor in addition to correspondence with authors, editing, proofing galley, and preparing page proof). With Bernard Boivin (Cody and Boivin 1954*), detective work allowed the mailing dates (important for dating original taxa descriptions) to be compiled for previous issues. Bill reduced his non-journal responsibilities in the OFNC in 1968, when the increasing size of the journal made it necessary to make its business manager a separate position.

Bill was instrumental in the financial survival and growth of the journal through several lean years following World War II and in its growing importance in publishing original contributions to northern North American natural history (Cook 1987). His tenure spanned the terms of five very different editors (Harold Senn till 1955), Bob Hamilton (1956-1961), Francis Cook (1962-1966), Ted Mosquin (1967-1972), Lorraine Smith (1972-1981), and Francis Cook again (1981 to 2010), during which time the journal grew from 150 pages a year (1946) to $400-800$ pages. Each editor brought individual idiosyncrasies and innovations and progressive editorial improvements that changed the format and emphasis of the journal. Yet its basics remained the same - a peer-reviewed journal of original research and observations that is interesting and readable for both naturalists and scientists, specialists and generalists. This stability was helped in large measure by Bill's continuous presence (Cook 2010). He also made a fundamental contribution to the journal's independent status, supported by journal subscriptions, club memberships, and page charges to authors. This was supplemented externally only by a small annual postage grant from the federal Department of Canadian Heritage. He continued to serve as business manager of The Canadian Field-Naturalist and actively helped maintain it as one of Canada's premier biodiversity and field biology journals until 2007, when he became honorary business manager. That is 59 years! As much as anything else, Bill was an Ottawa Field-Naturalist, like Frank Pope, James Fletcher, Percy Taverner, Sheila Thomson, Joyce Reddoch and all the rest, linked by the common thread of natural values (so aptly put by Brunton (2004), who himself belongs in the same group).

Cook (2010) has remarked that every visit he made to the Saunders Building on the Central Experimental Farm was marked by the friendly and cordial atmos- 
phere among both scientists and support staff, due in no small part, one suspects, to the tone set by the always cheerful Bill. Throughout his years on OFNC Council, Bill hardly ever missed a meeting, and the Council had to wait for a rare absence in 1979 to elect him (by surprise to avoid his protest) as an honorary member for his, even at that time, long service (Anonymous 1980). For many years, the OFNC Publications Committee meetings, which Bill also never missed, were held over bag lunches at noon at the Saunders Building, with Bill invariably greeting each committee member with a choice of tea or instant coffee.

For all business manager correspondence and invoices, Bill was never weaned from his trusted manual typewriter dating from the 1940s (Cook 2010). Failed efforts were made, including moving a computer into his office for an extended period; it was ignored. In contrast, when others at Agriculture and Agri-Food Canada began having their manuscripts entered into computers, he joined in by having his processed by staff or daughter Leslie. In the early 1980s, he was among the first to submit a disc to The Canadian FieldNaturalist along with the traditional hard copy of the manuscript. The journal's printing company at the time first regarded these discs as more bother than help to the typesetters, but within a couple of years would complain if a manuscript came without a disc. This rapid change was aided by relentless championing from the sometimes otherwise Luddite-seeming Bill. He had quickly realized that author-produced discs, though needing editorial additions, would save significant typesetting time and allow him to negotiate a reduction of costs with the printer, and he was unhesitatingly in favour of promoting this. It is likely that today, with the steadily rising postal costs, Bill would have even supported the journal's current move to computer-generated invoices and e-mailed dispatch of galley and reprint order forms to authors (Cook 2010).

Although it is Bill's service to The OFNC that stands out, he helped a number of other organizations. For example, in 1965 he served as the first treasurer and was a founding member of the Canadian Botanical Association, which has became an influential national society (Taylor 1969). In the late 1990s, he joined the Flora of North America project, providing extensive support and applying his extensive knowledge of phytogeography as a regional reviewer.

\section{Recognition and Awards}

Species named in his honour

Four plants have been named in Bill's honour:

Arabis codyi Mulligan (Rhodora 97: 151. 1995) with a type locality west of Kluane Lake.

Ranunculus codyanus Boivin (Canadian FieldNaturalist 65: 3-4. 1951) with type locality at Coral Harbour, Southampton Island.
Puccinia codyi Savile (Fungi Canadenses Number. 46. 2 pages (1974) with type locality in the Mackenzie Mountains, Northwest Territories..

Saxifraga codyana Zhmylev (Bulletin of Moscow Society of Naturalists Biological Series 97(1): 9596. 1992) collected at $69^{\circ} 13^{\prime} \mathrm{N}, 139^{\circ} 35^{\prime} \mathrm{W}$, in the Buckland Hills, Firth River drainage, Ivvavik National Park (then known as Northern Yukon National Park Reserve). This taxon was later treated as Saxifraga bronchialis ssp. codyana.

\section{6 - Richards Education Award}

On Thursday, 7 November 1996, at the 65th anniversary dinner of the Federation of Ontario Naturalists, The Ottawa Field-Naturalists' Club received the Richards Education Award. The award recognized the very special contribution to natural history education made by The Canadian Field-Naturalist (Pope 1997). Although the award was given to The OFNC, it was the relentlessly effective team of the journal business manager, Bill Cody, and its editor at the time, Francis Cook and his predecessors, backed up by a Publications Committee chaired effectively by Ron Bedford, that was largely responsible (Figure 8). Bill's work for The CFN was also highlighted by the Queen's Golden Jubilee Commemorative Medal (see page 84).

The Canadian Field-Naturalist began with the Transactions in 1880, which became The Ottawa Naturalist in 1887, which in turn became The Canadian FieldNaturalist in 1919. For more on CFN history and its significant reconfiguration in 1970 to a stronger conservation orientation, see Brunton (2004). The Canadian Field-Naturalist may be one of the biggest success stories of the OFNC. It has become a very popular, influential and respected journal of science and natural history and one of the leading field biology journals in Canada. It is used by naturalists and professional biologists alike. It has strongly influenced conservation and is the major source of education in field biology in Canada. The OFNC is in good company as a recipient of this award. Among the others who have received it are Dan Strickland and Ron Tozer for their interpretation programs in Algonquin Park; these programs not only educated many thousands but also contributed to the development of the largest group of expert and influential field biologists in Canada.

\section{7 - Distinguished Technical Communications Award}

The Society for Technical Communications found Bill's book, Flora of the Yukon Territory, to be a masterpiece of communication. Indeed, the design was in some respects a little ahead of its time, with illustrations, distributions maps, and brief text providing a wealth of information in a very easy to use format. Bill worked with designer and artist Marcel Jomphe to achieve this excellent example of technical communication. The reviews were very favourable. In the journal Taxon (International Association for Plant Taxonomy), 
the review of the book starts, "Doubleplusgood! Wow! Most impressive! Lavishly done!... are some instant reactions ..." (Schmid 1997). David Murray of the University of Alaska had used his copy so much that it was almost destroyed by the time he reviewed it (Murray 1997). See also Catling (1997).

\section{7 - Lawson Medal}

In 1997, Bill received the most prestigious award given by the Canadian Botanical Association (Chinnappa 1997). The Lawson Medal provides a collective formal expression of admiration and respect for excellence from the botanical science community across the country and internationally. Bill received this award for his work on the distribution, ecology, and classification of the plants of the Yukon Territory, gathered together in a monumental volume of 643 pages published by NRC Research Press. This work, Flora of the Yukon Territory (Cody 1996b*; 2nd edition, Cody 2000a*), is essential, not only as a basis for the protection of plant biodiversity but also for biological research and ongoing work relating to forestry, sustainable resource management, and wildlife management in the north. It included much new information and many discoveries as well as a thorough compilation and a novel analysis. It is a masterpiece of botanical science. In addition to this award for scientific content, it received a communication award (see above).

\section{8 - Special OFNC Service Award}

On 18 September 1998, a special reception was organized to recognize Bill's 50 years of service to The Ottawa Field-Naturalists' Club. He had already been made an honorary member for 33 years of service in 1979 (the same year as legendary Canadian field biologist C. H. D. Clarke was made an honorary member) (Anonymous 1980). Bill's 40-year landmark had also been recognized in 1987 (Cook 1987). At the reception in 1998, past presidents Bill Gummer and Frank Pope made outstanding presentations, actually some of the best presentations ever witnessed at an event of this kind, with CFN editor Francis Cook adding additional remarks. Bill received an exquisite carving of a Black-capped Chickadee from Ellaine Dickson and a plaque with a drawing of a Walking Fern and an inscription: "This plaque is presented to William J. Cody by The Ottawa Field-Naturalists' Club in recognition of 50 years of outstanding service as Council Member and Business Manager of The Canadian Field-Naturalist (1948-1998), September 18, 1998." For more information on this award and the event, see Darbyshire and Taylor (1999) and Darbyshire (1998).

\section{2 - Queen's Golden Jubilee Commemorative Medal}

In November 2002, Bill received a Queen's Golden Jubilee Commemorative Medal. These medals marked the 50th anniversary of the accession of Queen Eliza-

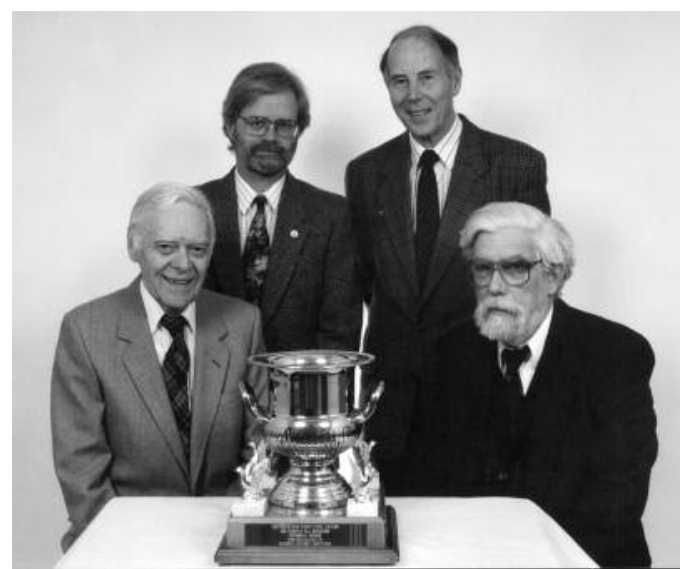

FIGURE 8. Richards Natural History Award trophy. Sitting in front are Bill Cody (left, Canadian Field-Naturalist business manager) and Francis Cook (right, Canadian Field-Naturalist editor). Standing behind are Dave Moore (left, OFNC president) and Ron Bedford (right, OFNC Publications Committee chair).

beth II to the throne. They were awarded to a limited number of people who had made a significant contribution to Canada, in this case, "especially for his work on The Canadian Field-Naturalist, Canada's foremost scientific journal for field biology." Bill has served as the business manager and reviewer for this journal for more than 50 years, and his influence on its development, improvement and content is beyond question. See also Richards Education Award, above.

\section{6 - Yukon Biodiversity Awareness Award}

In 2006, Bill received the Yukon Biodiversity Awareness Award in recognition of his enormous contribution to the understanding of the Yukon flora. Bill's 643-page textbook, Flora of the Yukon Territory, was first published in 1996. It included current information on status, distribution, ecology, classification, and identification. A second, updated edition of the book was published by NRC Research Press in 2000. Bill was also author of 15 scientific papers on the flora of Yukon. Botanical work in Yukon was a large part of Bill's northern botanical legacy (Bennett and Catling 2009 and see above). Always willing to help, he identified a thousand plants from Yukon every year. It is therefore no surprise that Bill was recognized for his outstanding service with the Yukon Biodiversity Awareness Award. The award honours those who have made major contributions to educating people about biodiversity and its importance. The plaque that Bill received included a photo of one of Yukon's rarest plants, McBride's Phacelia (Phacelia mollis), which is a Beringian endemic (confined to the unglaciated area of Alaska and Yukon). For more information, see Anonymous (2004a,b). 
2006 - Honorary Degree from McMaster University

During the 1940s, a number of renowned Canadian botanists received their degrees from McMaster University. All but one of these earned a Ph.D. William James (Bill) Cody was the exception. It was a B.A. that he received in 1946. He eventually became a scientist, and many people addressed him respectfully as "Dr. Cody," thinking that he had the degree since most scientists did. It was 38 years later that Bill received an honorary degree from his alma mater, McMaster University in Hamilton. The university was sufficiently impressed with his outstanding scientific contributions to Canadian botany that it made him Dr. Bill Cody honoris causa (for the sake of honour) (Anonymous 2007, 2008).

\section{Just remembering Bill}

The best short description of Bill may well be the 50 words that his family prepared for a memoriam. Much that is on that list has already been said here, but we have not mentioned that he was also an avid bridge player and an excellent square dancer. He liked to go for walks, but his children were always waiting for him to catch up because he had to examine every plant along the way. Bill will be remembered in different ways by different people. His smile (Figure 9) will be remembered by all. For us, he was remarkable for his achievements as a biologist and his value as a co-worker. For everyone he was a teacher by example, with optimism, modesty, dedication, and generosity. He will always be a cherished memory.

\section{Acknowledgments}

Help from Bill's family is much appreciated, particularly from Margaret Cody, who coordinated with the family to provide information, from Leslie CodyDurocher, who helped with Bill's publications and provided other valuable information, and from David, who provided detailed information on fieldwork with Bill in 2000. Bill himself also contributed much to this. He enjoyed talking about the past, but only when questioned, at a tea break (he hated coffee). Many colleagues also provided information about Bill's achievements. We also very much appreciate the editorial help of Liz Morton and useful comments of Ron Bedford, Frank Pope, Joyce Reddoch and Karen McLachlan Hamilton.

\section{Literature Cited}

Anderson, J. P. 1959. Flora of Alaska and adjacent parts of Canada. Iowa State University Press, Ames, Iowa. 543 pages.

Anonymous. 1980. New honorary members of the Ottawa Field-Naturalists' Club. Canadian Field-Naturalist 94(3): 345-346.

Anonymous. 2003. A Golden Jubilee Medal to Bill Cody. Canadian Botanical Association Bulletin 36(1): 1.

Anonymous. 2004a. Bill Cody receives Yukon Biodiversity Awareness Award. Canadian Field-Naturalist 120(2): 258259.

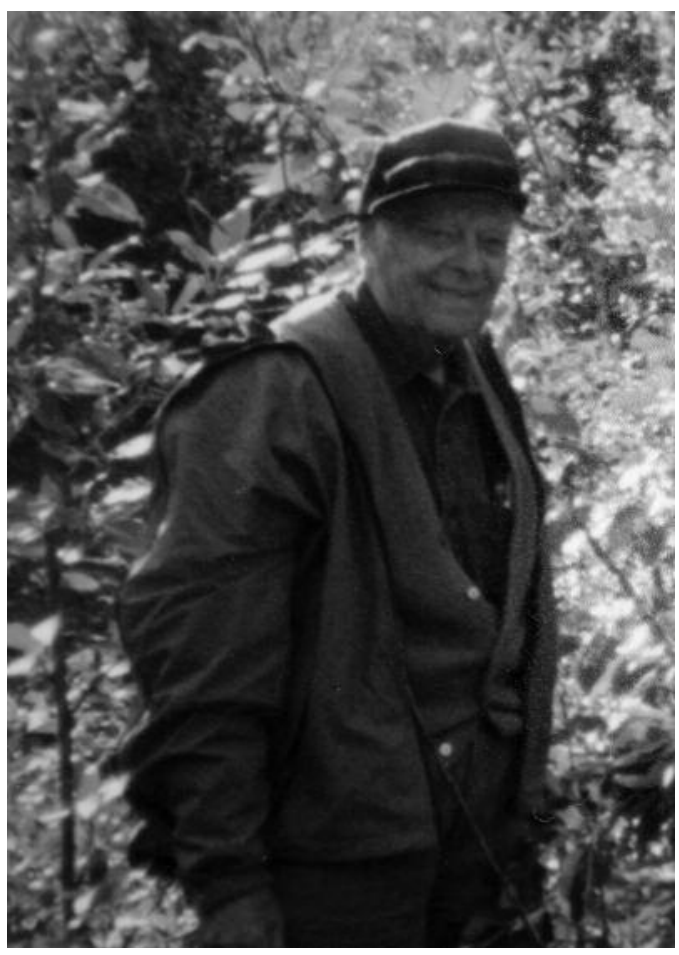

FIGURE 9. Bill Cody with his characteristic smile in 2001 at Lapie River canyon (near Ross River), Yukon. Photo by Margaret Cody during her trip to Yukon with Bill.

Anonymous. 2004b. Yukon Biodiversity Awareness Award 2006 - W. J. "Bill” Cody. Botanical Electronic News 363: $1-2$.

Anonymous. 2007. Honorary doctorate for William J. (Bill) Cody. Botanical Electronic News 380: 1.

Anonymous. 2008. Mr. Bill Cody, honorary doctorate of science, June 2, 2007. Trail \& Landscape 42(1): 4-5.

Barrington, D. S. 1990. Book Review, Ferns and fern allies of Canada. Rhodora 92(871): 207-208.

Benner, J. 2005. Bill Cody - a passion for the north. Friends of the Central Experimental Farm. Winter 2005. 9.

Bennett, B. A., and P. M. Catling. 2009. William (Bill) J. Cody: a legacy of contributions to northern Canadian botany. Botanical Electronic News (E-journal) 410: 1-5. http://www.ou.edu/cas/botany-micro/ben/ben410.html and: http://bomi.ou.edu/ben/410/bill-cody-bibliography.pdf

Boivin, B. 1980. Survey of Canadian herbaria. Provancheria 10: 1-187.

Britton, D. M. 1979. Review of Ferns of the Ottawa District. Canadian Field-Naturalist 93(3): 345.

Brunton, D. F. 2003. Donald M. Britton at the occasion of his 80th birthday on March 6th, 2003. Botanical Electronic News 304-305: 1-2.

Brunton, D. F. 2004. Origins and history of the Ottawa Field-Naturalists' Club. Canadian Field-Naturalist 118(1): 1-38.

Catling, P. M. 1991. 1991 Lawson Medals. Canadian Botanical Association Bulletin 24(4): 64-67. 
Catling, P. M. 1997. Review of Flora of the Yukon Territory. Canadian Botanical Association Bulletin 30(2): 27-30.

Catling, P. M. 2003. Three remarkable volunteers at the DAO vascular plant herbarium, Agriculture and Agri-Food Canada. Botanical Electronic News 310: 3-4. http://www. ou.edu/cas/botany-micro/ben/ben310.html

Catling, P. M. 2009. Passing of Bill Cody. AAFC News. 1 page.

Catling, P. M., and P. T. Dang. 1992. Collections overview - an overview of their perception, needs and significance. Pages 27-38 + figures in Proceedings of the Workshop on Systematics. Edited by P. Marriage. University of Ottawa, 16-17 June 1992. Agriculture Canada, Research Branch Publication A52-69/1992E.

Catling, P. M., G. Mitrow, and B. A. Bennett. 2008. A compilation of additions to the flora of the continental portions of Northwest Territories and Nunavut - number 2. Botanical Electronic News (E-journal) 400 (October 2008): 2-12.

Catling, P. M., G. Mitrow, and J. Cayouette. 2009a. William James (Bill) Cody (1922-2009). Canadian Botanical Association Bulletin 42(2): 37-38. Also Flora of North America Newsletter 23(1): 10-11.

Catling, P. M., G. Mitrow, and J. Cayouette. 2009b. The Vascular Plant Herbarium. About the Vascular Plant Herbarium, History of the Vascular Plant Herbarium, How the Vascular Plant Herbarium is Organized, How the Vascular Plant Herbarium is Used, The Importance of the Vascular Plant Herbarium, Catalogue of Type Specimens, The National Vascular Plant Identification Service, Specimen Exchange Program, Collection Databases, Collecting Specimens, References for Identification, Depositing a Cultivar Voucher, Requesting a Loan, Requesting a Journal Reprint, Guidelines for Visitors http://www4.agr.gc.ca/AAFC-AAC/ display-afficher.do?id=1251393521021\&lang=eng, Agriculture and Agri-Food Canada/Agriculture et Agroalimentaire Canada, Ottawa, Ontario. (Available online)

Cayouette, J. 1989. Review of Flore du parc national du mont Riding, Manitoba. Le Naturaliste canadien 116: 283284.

Cayouette, J. 2009. Bill Cody (1922-2009), un maître de la flore nordique. FloraQuebeca 14(2): 13-14.

Chinnappa, C. C. 1997. Awards at Montreal. Canadian Botanical Association Bulletin 30(4): 58-59.

Cody, L. S. 1954. The Cody family in America. 1698. Cody Publications Inc., Kissimmee, Florida. 257 pages.

Cook, F. 1987. A continuing salute: William James Cody: Managing the Canadian Field-Naturalist. Canadian FieldNaturalist 101(2): 159-160.

Cook, F. R. 2010. On missing Bill: Recollections from 5 decades. Trail \& Landscape 44(2): 58-61.

Darbyshire, S. 1998. Yet another milestone for William James Cody. Canadian Field-Naturalist 112(4): 719-720.

Darbyshire, S., and K. Taylor. 1999. Yet another milestone for William James Cody. Trail \& Landscape 33(1): 3-5.

Desmarais, Y. 1957. Revue des livres. W. J. Cody - Ferns of the Ottawa district. Le Naturaliste canadien 84(1): 35.
Freeman, T. N. 1948. Entomological research in northern Canada progress report 1948, Part 1, The northern insect survey. Defence Research Board. Report No. D.R. 18. 36 pages + appendices.

Freeman, T. N. 1954. Present trends and future needs of entomological research in northern Canada. Part 1. The northern insect survey. Arctic 7: 275-279.

Freeman, T. N. 1959. The Canadian Northern Insect Survey 1947-57. The Polar Record 9(61): 299-307.

Gillett, J. M. 1980. Transactions of the Ottawa Field-Naturalists' Club and the Ottawa Naturalist Index. Ottawa FieldNaturalists' Club Special Publication No. 2. 195 pages.

Hooker, W. J. 1829-1940. Flora Boreali-Americana. London.

McLachan Hamilton, K. 2010. William (Bill) James Cody. Trail \& Landscape 44(1): 4-6.

Hultén, E. 1941-1950. Flora of Alaska and Yukon, 1-10. Lunds Universitets Arsskrift N. F., Aud. 2. Vols. 37-46. 1902 pages.

Hultén, E. 1968. Flora of Alaska and Neighboring Territories - A Manual of the Vascular Plants. Stanford University Press, Stanford, California. 1008 pages.

Martin, V. 1990. Review. Ferns and fern allies of Canada. Seasons (Federation of Ontario Naturalists) (Winter 1990): 43.

Moore, R. J., and W. F. Grant. 1965. Lulu Odell Gaiser, 1896-1965. Genome 7(3): 361-362.

Munro, D. 1979. A floristic study of Kouchibouguac National Park; a survey of vascular herbs, shrubs, and trees. Report, Biosystematics Research Institute, Ottawa. 213 pages + appendices.

Murray, D. F. 1997. Review of Flora of the Yukon Territory. Systematic Botany 22: 596-597.

Polunin, N. 1940. Botany of the Canadian eastern Arctic. Part 1. Pteridophyta and Spermatophyta. National Museum of Canada Bulletin 92: 1-408.

Pope, F. 1997. Richards Natural History Education Award. Trail \& Landscape 31(2): 41-42.

Pope, F. 2010. Bill Cody and the Ottawa Field-Naturalists. Some reflections upon the man I knew. Trail \& Landscape 44(1): 6-8.

Porsild, A. E. 1943. Materials for a flora of the continental Northwest Territories of Canada. Sargentia 4: 1-79.

Porsild, A. E. 1945. Alpine flora of the east slope of Mackenzie Mountains, Northwest Territories. National Museum of Canada Bulletin 101: 1-35.

Pringle, J. S. 1995. The history of the exploration of the vascular flora of Canada. Canadian Field-Naturalist 109: 291-356.

Raup, H. M. 1947. The botany of southwestern Mackenzie. Sargentia 6: 1-262.

Schmid, R. 1997. Review of Flora of the Yukon Territory. Taxon 46: 150.

Taylor, R. L. 1969. Founding of CBA - ABC - a review. Canadian Botanical Association Bulletin 2(2): 5, 8 .

Walsh, R. J., and M. S. Salsbury. 1928. The making of Buffalo Bill. The Bobbs-Merrill Company (reprinted 1978). Cody Publications Inc., Kissimmee, Florida. 391 pages. 


\section{Appendix 1. W. J. Cody - Referred publications, books and reports, in chronological order}

For a list of Bill's book reviews, encyclopedia contributions, and other miscellaneous publications, see Appendix 2. All of Bill's northern work is included here but, for a complete list of his publications dealing with northern Canada alone (and separated for the territories), as well as a general outline of Bill's northern work, see Bennett and Catling (2009). Reports are preceded by an asterisk.

*Cody, W. J. 1949. Report on the field work at Coral Harbour, Southampton Island, 1948. Appendix D in Part III. Botanical Associations of the Northern Biting Flies. Entomological Research in Northern Canada Progress Report. Defence Research Board, Canada. Report Number D.R. 20.

Cody, W. J. 1950. Plants collected by B. John Woodruff on the west coast of Melville Peninsula, Franklin District, N.W.T., Canada. Canadian Field-Naturalist 64: 90-92.

Cody, W. J. 1951a. Additions and annotations to the flora of Southampton Island, Northwest Territories, Canada. Canadian Field-Naturalist 65: 140-143.

Cody, W. J. 1951b. Plant collections at Ross Bay, Melville Peninsula, N.W.T. Canadian Field-Naturalist 65: 191-194.

Cody, W. J. 1952. Chrysopsis falcata adventive in Canada. Rhodora 54: 308.

Cody, W. J. 1953a. A plant collection from the west side of Boothia Isthmus, N.W.T., Canada. Canadian Field-Naturalist 67: 40-43.

Cody, W. J. 1953b. Phyllodoce coerulea in North America. Canadian Field-Naturalist 67: 131-134.

Cody, W. J. 1954a. New plant records from Bathurst Inlet, N.W.T. Canadian Field-Naturalist 68: 40.

Cody, W. J. 1954b. Plant records from Coppermine, Mackenzie District, N.W.T. Canadian Field-Naturalist 68: 110-117.

Cody, W. J. 1954c. Salicornia europaea in the James Bay region. Rhodora 56: 61-62.

Cody, W. J. 1954d. A history of Tillaea aquatica (Crassulaceae) in Canada and Alaska. Rhodora 56: 96-101.

Cody, W. J., and B. Boivin. 1954. The Canadian FieldNaturalist and its predecessors. Canadian Field-Naturalist 68: 127-132.

Boivin, B., and W. J. Cody. 1955. Bibliographic survey of James Fletcher's Flora Ottawaensis. Canadian FieldNaturalist 69: 79-82.

Cody, W. J. 1955. The glandular form of the Oak Fern. American Fern Journal 45: 126.

Cody, W. J., and J. G. Chillcott. 1955. Plant collections from Matthews and Muskox Lakes, Mackenzie District, N.W.T. Canadian Field-Naturalist 69: 153-162.

Schofield, W. B., and W. J. Cody. 1955. Botanical investigations on coastal southern Cornwallis Island, Franklin District, N.W.T. Canadian Field-Naturalist 69: 116-128.

Boivin, B., and W. J. Cody. 1956. The variations of Lilium canadense Linnaeus. Rhodora 58: 14-20.

Cody, W. J. 1956a. New plant records for northern Alberta and southern Mackenzie District. Canadian Field-Naturalist 70: 101-130.

Cody, W. J. 1956b. Ferns of the Ottawa District. Agriculture Canada Publication No. 974: 1-94.

Cody, W. J. 1957. Draba lanceolata in the Ottawa district. Rhodora 59: 237-239.

*Dore, W. G., F. H. Montgomery, S. C. Zoltai, and W. J. Cody. 1959. Field trip 9, southern Ontario. IX International Botanical Congress. 40 pages.

Cody, W. J. 1960. Plants of the vicinity of Norman Wells, Mackenzie District, Northwest Territories. Canadian FieldNaturalist 74: 71-100.
Bowden, W. M., and W. J. Cody. 1961. Recognition of Elymus sibiricus L. from Alaska and the District of Mackenzie. Bulletin of the Torrey Botanical Club 88: 153-155.

Cody, W. J. 1961a. New plant records from the upper Mackenzie River valley, Mackenzie District, Northwest Territories. Canadian Field-Naturalist 75: 55-69.

Cody, W. J. 1961b. Iris pseudacorus L. escaped from cultivation in Canada. Canadian Field-Naturalist 75: 139-142.

Cody, W. J. 1961c. New forms in Botrychium virginianum. American Fern Journal 51: 36-37.

Cody, W. J. 1962a. Sorbaria sorbifolia (L.) A. Br. False Spiraea, persisting and spreading after cultivation in Canada. Canadian Field-Naturalist 76: 104-107.

Cody, W. J. 1962b. A new station for Pinguicula vulgaris in Ontario. Rhodora 64: 182-183.

Cody, W. J. 1963a. A contribution to the knowledge of the flora of southwestern Mackenzie District, N.W.T. Canadian Field-Naturalist 77: 108-123.

Cody, W. J. 1963b. Some rare plants from the Mackenzie Mountains, Mackenzie District, N.W.T. Canadian FieldNaturalist 77: 226-228.

Cody, W. J. 1963c. Woodwardia in Canada. American Fern Journal 53: 17-27.

*Cody, W. J. 1963d. Reindeer Range Survey 1957 and 1963. Agriculture Canada, Plant Research Institute. 15 pages.

Cody, W. J. 1965a. New plant records from northwestern Mackenzie District, N.W.T. Canadian Field-Naturalist 79: 96-106.

*Cody, W. J. 1965b. Plants of the Mackenzie River Delta and Reindeer Grazing Preserve. Canada Agriculture, Research Branch. 56 pages.

*[Taylor, R. L., and W. J. Cody]. 1965. Canadian botanists. Agriculture Canada, Plant Research Institute. 55 pages.

*Cody, W. J. 1966. New Herbarium Equipment. Agriculture Canada, Plant Research Institute. 7 pp.

Cody, W. J. 1967a. Sedum in the Ottawa District. Canadian Field-Naturalist 81: 273-274.

Cody, W. J. 1967b. Elymus sibiricus (Gramineae) new to British Columbia. Canadian Field-Naturalist 81: 275.

Cody, W. J. 1967c. The Plant Research Institute herbaria. Arboretum and Botanical Garden Bulletin 1: 17-20

Cody, W. J., and A. E. Porsild.1967. Potamogeton illinoensis, new to Mackenzie District. Blue Jay 25: 28-29.

Hoffman, I., F. S. Nowosad, and W. J. Cody. 1967. Ascorbic acid and carotene values of native eastern Arctic plants. Canadian Journal of Botany 45: 1859-1862.

Cody, W. J. 1968. Polystichum acrostichoides $\times$ lonchitis versus $P . \times$ marginale. American Fern Journal 58: 30-31.

Cody, W. J., and A. E. Porsild. 1968. Additions to the flora of continental Northwest Territories, Canada. Canadian FieldNaturalist 82: 263-275.

Mulligan, G. A., and W. J. Cody. 1968a. Draba norvegica, disjunct to the Mackenzie District, Northwest Territories, Canada. Canadian Journal of Botany 46: 1334-1335.

Mulligan, G. A., and W. J. Cody. 1968b. Page 286 in IOPB chromosome number reports, XVII. Edited by Á. Löve. Taxon 17: 285-288. 
Porsild, A. E., and W. J. Cody. 1968. Checklist of the Vascular Plants of Continental Northwest Territories. Agriculture Canada, Plant Research Institute. 102 pp.

Cody, W. J. 1969. Asplenium trichomanes new to Newfoundland. American Fern Journal 58: 179-180.

Hopkins, C. Y., M. J. Chisholm, and W. J. Cody. 1969. Fatty acid components of some Santalaceae seed oils. Phytochemistry 8: 161-165.

Mulligan, G. A., and W. J. Cody. 1969. The highest chromosome number known to occur in a North American plant. Canadian Field-Naturalist 83: 277-278.

Cody, W. J. 1970. Paronychia fastigiata (Caryophyllaceae), forked chickweed new to Ontario. Canadian Field-Naturalist 84: 58-59.

Cody, W. J. 1971a. A phytogeographic study of the floras of the continental Northwest Territories and Yukon. Le Naturaliste canadien 98: 145-158.

Cody, W. J. 1971b. Plant Research Institute botanical activities in northern Canada, 1948-1971. Greenhouse-GardenGrass 10: 14-17.

Cody, W. J., and C. Frankton. 1971. Ragged Robin, Lychnis flos-cuculi L. (Caryophyllaceae), in Canada. Canadian Field-Naturalist 85: 256-257.

Mulligan, G. A., and W. J. Cody. 1971. Pages 613-614 in IOPB chromosome number reports XXXIII. Edited by Á. Löve. Taxon 20: 609-614.

Mason, W. R. M., G. E. Shewell, and W. J. Cody. 1972. A plant collection from the southern interior of Banks Island, N.W.T. Canadian Field-Naturalist 86: 363-367.

Mulligan, G. A., and W. J. Cody. 1972. Page 163 in IOPB chromosome number reports XXXV. Edited by Á. Löve. Taxon 21: 161-166.

Mulligan, G. A., L. Cinq-Mars, and W. J. Cody. 1972a. Natural interspecific hybridization between sexual and apogamous species of the beech fern genus Phegopteris Fée. Canadian Journal of Botany 50: 1295-1300.

Mulligan, G. A., W. J. Cody, and N. Grainger. 1972b. Pages 498-499 in IOPB chromosome number reports XXXVII. Edited by Á. Löve. Taxon 21: 495-500.

Cody, W. J. 1973. Ram's-head Lady's-slipper rediscovered in Saskatchewan. Blue Jay 31: 180-181.

Cody, W. J., and B. Boivin. 1973. Purple Coneflower, Echinacea purpurea, in Ontario. Canadian Field-Naturalist 87: 70 .

Cody, W. J., and K. Shaw. 1973. Canada plum in southwestern Alberta. Blue Jay 31: 217-218.

Cody, W. J., and K. W. Spicer. 1973. Report on the vascular plant herbarium - 1972. Greenhouse-Garden-Grass 12: 27-32.

Cody, W. J., and S. S. Talbot. 1973. The pitcher plant, Sarracenia purpurea $\mathrm{L}$. in the northwestern part of its range. Canadian Field-Naturalist 87: 318-320.

Mulligan, G. A., and W. J. Cody. 1973a. Pages 290-291 in IOPB chromosome number reports XL. Edited by Á. Löve. Taxon 22: 285-291.

Mulligan, G. A., and W. J. Cody. 1973b. A clarification of the chromosome number situation in Sanguisorba canadensis. Canadian Journal of Botany 51: 2075-2077.

Cody, W. J., and W. Krivda. 1974. Carex maritima Gunn., an adventive sedge at The Pas, Manitoba. Blue Jay 32: 25-26.

Cody, W. J., B. Boivin, and G. W. Scotter. 1974. Loiseleuria procumbens (L.) Desv., Alpine Azalea, in Alberta. Canadian Field-Naturalist 88: 229-230.
Mulligan, G. A., and W. J. Cody. 1974. Page 194 in IOPB chromosome number reports XLIII. Edited by Á. Löve. Taxon 23: 193-196.

Scotter, G. W., and W. J. Cody. 1974. Vascular plants of Nahanni National Park and vicinity, Northwest Territories. Le Naturaliste canadien 101: 861-891.

*Simmons, N.M. and W. J. Cody. 1974. A proposal for Ecological Reserves in the Northwest Territories: Plains of Abraham, Glacier Lake, Brackett Lake, Pilot Lake. Canadian Committee for the International Biological Program, Conservation of Terrestrial Ecosystems, Panel 10. 174 pages.

Wein, R. W., L. R. Hettinger, A. J. Janz, and W. J. Cody. 1974. Vascular plant range extensions in the northern Yukon Territory and northwestern Mackenzie District, Canada. Canadian Field-Naturalist 88: 57-66.

Cody, W. J. 1975a. Scheuchzeria palustris L. (Scheuchzeriaceae) in northwestern North America. Canadian FieldNaturalist 89: 69-71.

*Cody, W. J. 1975b. A phytogeographical study of the flora of St. Lawrence Islands National Park region. St. Lawrence Islands National Park Interpretation Contract. 65 pages + Appendix 1. The vascular plants of the Thousand Islands National Park region. 68 pp.

Cody, W. J., and C. W. Crompton. 1975. The biology of Canadian weeds. 15. Pteridium aquilinum (L.) Kuhn. Canadian Journal of Plant Science 55: 1059-1072.

Cody, W. J., and J. D. Lafontaine. 1975. The fern genus Woodsia in Manitoba. Canadian Field-Naturalist 89: 66-69.

Cody, W. J., and R. B. MacLaren. 1976. Additions and rediscoveries of five plant species in Prince Edward Island. Canadian Field-Naturalist 90: 53-54.

Cody, W. J., G. R. Parker, and D. B. M. Lamperd. 1976. Additions to the vascular flora of Melville Island, Franklin District, Northwest Territories. Canadian Field-Naturalist 90: 70-72.

*Cody, W. J. 1977. Ralph Anthony Ludwig. Bulletin of the Canadian Botanical Association 10(2): 14-15.

Cody, W. J., I. V. Hall, and C. W. Crompton. 1977. The biology of Canadian weeds. 26. Dennstaedtia punctilobula (Michx.) Moore. Canadian Journal of Plant Science 57: 1159-1168.

Cody, W. J. 1978a. Ferns of the Ottawa District. (Revised). Agriculture Canada, Research Branch Publication 974. 112 pages. [made available in French in 1980. Fougères du district d'Ottawa. Agriculture Canada, Direction de la recherche, Publication 974. 112 pages.]

*Cody, W. J. 1978b. Plants of the Thousand Islands. Island Insights No. 1. Parks Canada, Cornwall, Ontario. 63 pages.

Cody, W. J. 1978c. The status of Lythrum alatum (Lythraceae) in Canada. Canadian Field-Naturalist 92: 74-75.

Cody, W. J. 1978d. Range extensions and comments on the vascular flora of the continental Northwest Territories. Canadian Field-Naturalist 92: 144-150.

Cody, W. J., and S. S. Talbot. 1978. Vascular plant range extensions to the Heart Lake area, District of Mackenzie, Northwest Territories. Canadian Field-Naturalist 92: 137-143.

McNeill, J., and W. J. Cody. 1978. Species-area relationships for vascular plants of some St. Lawrence River islands. Canadian Field-Naturalist 92: 10-18.

Soper, J. H., and W. J. Cody. 1978a. Alf Erling Porsild, M.B.E., F.R.S.C. (1901-1977). Canadian Field-Naturalist 92: 299-304. 
*Soper, J. H., and W. J. Cody. 1978b. The publications of Dr. A. E. Porsild. Bulletin of the Canadian Botanical Association 11(2): 28-32.

Cody, W. J. 1979. Vascular plants of restricted range in the continental Northwest Territories, Canada. Syllogeus (National Museum of Natural Sciences) 23. 57 pages.

Cody, W. J., G. W. Scotter, and S. S. Talbot. 1979. Additions to the vascular plant flora of Nahanni National Park, Northwest Territories. Le Naturaliste canadien 106: 439450.

Mulligan, G. A., and W. J. Cody. 1979. Chromosome numbers in Canadian Phegopteris. Canadian Journal of Botany 57: 1815-1819.

Nagy, J. A., A. M. Pearson, B. C. Goski, and W. J. Cody. 1979. Range extensions of vascular plants in northern Yukon Territory and northwestern District of Mackenzie. Canadian Field-Naturalist 93: 259-265.

Scotter, G. W., and W. J. Cody. 1979. Interesting vascular plants from southeastern Yukon Territory. Canadian FieldNaturalist 93: 163-170.

Cody, W. J. 1980. Wolffia columbiana (Lemnaceae), watermeal, new to Manitoba. Canadian Field-Naturalist 94: 193-194.

Cody, W. J., and D. Munro. 1980. The genus Listera (Twayblades) in New Brunswick. Canadian Field-Naturalist 94: 443-446.

Gillett, J. M. 1980. Edited by W. J. Cody. Transactions of the Ottawa Field-Naturalists' Club and the Ottawa Naturalist Index. Ottawa Field-Naturalists' Club Special Publication No. 2. 195 pages.

Porsild, A. E., and W. J. Cody. 1980. Vascular plants of continental Northwest Territories. National Museum of Natural Sciences, Ottawa. 667 pages.

Cody, W. J., and V. Wagner. 1981. The biology of Canadian weeds. 49. Equisetum arvense L. Canadian Journal of Plant Science 61: 123-133.

Cody, W. J. 1982. A comparison of the northern limits of distribution of some vascular plant species found in southern Ontario. Le Naturaliste canadien 109: 63-90.

Cody, W. J., and G. A. Mulligan. 1982. Chromosome numbers of some Canadian ferns and fern allies. Le Naturaliste canadien 109: 273-275.

Cody, W. J. 1983a. Adiantum pedatum ssp. calderi, a new subspecies in northeastern North America. Rhodora 85: 93-96.

Cody, W. J. 1983b. Plant collecting in Ontario: the view from DAO. The Plant Press 1(2): 27-28.

Cody, W. J., and D. M. Britton. 1984. Polystichum lemmonii, a rock shield-fern new to British Columbia and Canada. Canadian Field-Naturalist 98: 375.

Cody, W. J., and J. Saquet. 1984. Pinesap, Monotropa hypopithys, new to the flora of Manitoba. Canadian FieldNaturalist 98: 256-257.

Cody, W. J., G. W. Scotter, and S. C. Zoltai. 1984a. Additions to the vascular plant flora of the Bathurst Inlet region, Northwest Territories, Canada. Canadian Field-Naturalist 98: 171-177.

Cody, W. J., G. W. Scotter, and S. C. Zoltai. 1984b. Additions to the vascular plant flora of Bylot Island, Northwest Territories. Canadian Field-Naturalist 98: 485-488.

Britton, D. M., W. G. Stewart, and W. J. Cody. 1985. Cystopteris protrusa, Creeping Fragile Fern, an addition to the flora of Canada. Canadian Field-Naturalist 99: 380382 .
*Cody, W. J. 1985. In Memoriam, Bernard Boivin, F.R.S.C. Canadian Botanical Association Bulletin 18(3): 21.

Cody, W. J., and D. M. Britton. 1985. Male Fern, Dryopteris filix-mas, a phytogeographically important discovery in northern Saskatchewan. Canadian Field-Naturalist 99: 101-102.

Cody, W. J. 1986a. Agriculture Canada Research Branch Centennial 1886-1986. Canadian Field-Naturalist 100: 418-422.

Cody, W. J. 1986b. Compactor systems installed for DAO and DAOM herbaria. The Plant Press 4: 100-101.

Cody, W. J., and J. Cayouette. 1986. A tribute to Bernard Boivin, 1916-1985. Canadian Field-Naturalist 100: 280288.

Cody, W. J., and W. L. Putman. 1986. A hawk's-beard, Crepis pulchra, adventive in Ontario. Canadian FieldNaturalist 100: 376-377.

Cody, W. J., D. B. O. Savile, and M. J. Sarazin. 1986. Systematics in Agriculture Canada at Ottawa 1886-1986. Agriculture Canada Historical Series No. 28. 81 pages. / La Recherche en systématique à Agriculture Canada 18861986. 83 pages.

Parmelee, J. A., and W. J. Cody. 1986. Compactor installations for collections of fungi and plants in the Biosystematics Research Centre. Agriculture Canada Publication. 8 pages.

Barr, D. J. S., W. J. Cody, and J. A. Parmelee. 1987. State-of-the-art herbarium compactor systems for DAO and DAOM. Taxon 36: 413-421.

Catling, P. M., and W. J. Cody. 1987. Botanical research in Canadian parks. Park News Magazine (Summer): 13-15.

Cody, W. J. 1988a. Hornseed Buttercup, Ceratocephalus testiculatus: a new record for the adventive flora of Saskatchewan. Canadian Field-Naturalist 102: 71-73.

Cody, W. J. 1988b. Plants of Riding Mountain National Park, Manitoba. Agriculture Canada, Research Branch Publication 1818/E. 320 pages. [Also made available in French, 1988. Flore du Parc national du mont Riding, Manitoba. Agriculture Canada, Direction générale de la recherche, Publication 1818/F. 340 pp.]

Cody, W. J., and F. W. Schueler. 1988. A second record of the Mosquito Fern, Azolla caroliniana, in Ontario. Canadian Field-Naturalist 102: 545-546.

Cody, W. J., M. Blondeau, and J. Cayouette. 1988. Ranunculus $\times$ spitzbergensis (Nath.) Hadač, an addition to the flora of North America. Rhodora 90: 27-36.

Cayouette, J., and W. J. Cody. 1989. Bernard Boivin (1916 Quatre-Temps (SAJIB [Société d'animation du Jardin et de l'Institut botaniques]) 13(3): 2-11.

Cody, W. J., and D. M. Britton. 1989. Ferns and fern allies of Canada. Agriculture Canada, Research Branch Publication 1829/E. 430 pages. [Also made available in French, 1989. Les fougères et les plantes alliées du Canada. Agriculture Canada, Direction générale de la recherche, Publication 1829/F. 452 pages.]

Cody, W. J., G. W. Scotter, and S. C. Zoltai. 1989. Vascular plant flora of the Wager Bay region, District of Keewatin, Northwest Territories. Canadian Field-Naturalist 103: 551559.

*Cody, W. J. 1990. Recent death. James (Jim) A. Calder. Herbarium News 10(3): 19. Also reproduced in Canadian Botanical Association Bulletin 23(2): 21, 1990.

Cody, W. J., and G. W. Scotter. 1990. New records for the Alberta flora: Geranium pratense, Meadow Crane's-bill, 
and Anemone canadensis f. dicksonii, a Canada Anemone form. Canadian Field-Naturalist 104: 600-602.

Cody, W. J., S. J. Darbyshire, and C. E. Kennedy. 1990. A Bluegrass, Poa pseudoabbreviata Roshev., new to the flora of Canada, and some additional records from Alaska. Canadian Field-Naturalist 104: 589-591.

Cody, W. J., and J. Cayouette. 1991. A tribute to James Alexander Calder, 1915-1990. Canadian Field-Naturalist 105: 584-591.

*Cody, W. J. 1992. Type specimens in DAO. Herbarium News 12(5/6): 20.

Cody, W. J., G. W. Scotter, and S. C. Zoltai. 1992. Vascular plant flora of the Melville Hills region, Northwest Territories. Canadian Field-Naturalist 106: 87-99.

Wein, R. W., G. Wein, S. Bahret, and W. J. Cody. 1992. Northward invading non-native vascular plant species in and adjacent to Wood Buffalo National Park, Canada. Canadian Field-Naturalist 106: 216-224.

Cody, W. J. 1994a. Nomenclatural changes and new taxa for the Yukon flora. Canadian Field-Naturalist 108: 93-95.

Cody, W. J. 1994b. The flora of the Yukon Territory: additions, range extensions and comments. Canadian FieldNaturalist 108: 428-476. [See also addendum 109: 266. 1995.]

Lichvar, R. W., and W. J. Cody. 1994. Yukon, Botrychium multifidum (Gmel.) Rupr. var. multifidum (Ophioglossaceae). Madroño 41: 232-233.

McJannet, C. L., G. W. Argus, and W. J. Cody. 1995. Rare vascular plants in the Northwest Territories. Syllogeus No. 73. 104 pages.

Mulligan, G. A., and W. J. Cody. 1995. New information on the problem of Asiatic Cress, Rorippa crystallina Rollins (Brassicaceae). Canadian Field-Naturalist 109: 111-112.

Cody, W. J. 1996a. Additions and range extensions to the vascular plant flora of the Northwest Territories, Canada. Canadian Field-Naturalist 110: 260-270.

Cody, W. J. 1996b. Flora of the Yukon Territory. NRC Research Press, Ottawa, Ontario, Canada. 643 pages.

*Cody, W. J. 1996c. Catalogue of Type Specimens in the Vascular Plant Herbarium (DAO). Internet http://res.agr.ca/ brd/dao. [Updated in 2000, 2002 and 2003]

Cody, W. J. 1997. A tribute to Harold Archie Senn, 19121997. Canadian Field-Naturalist 111: 671-675.

Cody, W. J. 1998a. A tribute to Hugh Miller Raup, 19011995. Canadian Field-Naturalist 112: 557-564.

Cody, W. J. 1998b. Horned Pondweed, Zannichellia palustris (Zannichelliaceae), new to the vascular plant flora of the continental Northwest Territories, Canada, and deleted from the flora of the Yukon Territory. Canadian FieldNaturalist 112: 711-712.

Cody, W. J., C. E. Kennedy, and B. Bennett. 1998. New records of vascular plants in the Yukon Territory. Canadian Field-Naturalist 112: 289-328.

Cody, W. J. 2000a. Flora of the Yukon Territory. Second edition. NRC Research Press, Ottawa. 669 pages.

Cody, W. J. 2000b. Addendum, Flora of the Yukon Territory. NRC Research Press, Ottawa, Ontario, Canada. 24 pages.
Cody, W. J. and K. L. MacInnes. 2000. Head Smut, Ustilago bullata on Slender Wheat Grass, Elymus trachycaulus, introduced along the Norman Wells pipeline, District of Mackenzie, Northwest Territories. Canadian FieldNaturalist 114: 138-141.

Cody, W. J., C. E. Kennedy, and B. Bennett. 2000a. New records of vascular plants in the Yukon Territory II. Canadian Field-Naturalist 114: 417-443.

Cody, W. J., K. L. MacInnes, J. Cayouette, and S. Darbyshire. 2000b. Alien and invasive native vascular plants along the Norman Wells pipeline, District of Mackenzie, Northwest Territories. Canadian Field-Naturalist 114: 126137.

Cody, W. J., C. E. Kennedy, and B. Bennett. 2001. New records of vascular plants in the Yukon Territory III. Canadian Field-Naturalist 115: 301-322.

Cody, W. J. 2002. Dryopteris $\times$ mickelii Peck, Simulated Log Fern, a newly named hybrid fern found in the Ottawa District. Trail \& Landscape 36(2): 43-45.

Cody, W. J., C. E. Kennedy, B. Bennett, and V. Loewen. 2002. New records of vascular plants in the Yukon Territory IV. Canadian Field-Naturalist 116: 446-474.

Staniforth, R. J., W. J. Cody, and K. A. Frego. 2002. Bill Dore's notes on the Kaladar Cactus (Opuntia fragilis). Canadian Field-Naturalist 116: 547-550.

Cody, W. J., and V. Johnston. 2003. Malaxis monophyllos var. brachypoda, One-leaved Malaxis, new to the Northwest Territories, Canada. Canadian Field-Naturalist 117: 302-303.

Cody, W. J., C. E. Kennedy, B. Bennett, and J. Staniforth. 2003a. New records of vascular plants in the Yukon Territory V. Canadian Field-Naturalist 117: 278-301.

Cody, W. J., K. L. Reading, and J. M. Line. 2003b. Additions and range extensions to the vascular plant flora of the continental Northwest Territories and Nunavut, Canada, II. Canadian Field-Naturalist 117: 448-465.

*Cody, W. J. and C. E. Kennedy. 2004. Flora of Herschel Island Territorial Park (checklist). Yukon Environment. 2 pages.

Cody, W. J., C. E. Kennedy, B. Bennett, and P. Caswell. 2004. New records of vascular plants in the Yukon Territory VI. Canadian Field-Naturalist 118: 558-578.

Catling, P. M., W. J. Cody, and G. Mitrow. 2005. A compilation of additions to the flora of the continental portions of Northwest Territories and Nunavut. Botanical Electronic News 352: 3-12. http://www.ou.edu/cas/botany-micro/ben/ ben353.html.

Cody, W. J., and K. L. Reading. 2005. Additions and range extensions to the vascular plant flora of the continental Northwest Territories and Nunavut, Canada III. Canadian Field-Naturalist 119: 276-290.

Cody, W. J., B. A. Bennett, and P. Caswell. 2005. New records of vascular plants in the Yukon territory VII. Canadian Field-Naturalist 119: 417-436.

Bennett, B. A., P. M. Catling, W. J. Cody, and G. W. Argus. 2010. New records of vascular plants in the Yukon Territory VIII. Canadian Field-Naturalist 124(1): 1-27. 


\section{Appendix 2. W. J. Cody - Miscellaneous publications}

Cody, W. J. 1960. Review of T. S. Cooperrider, The ferns and other pteridophytes of Iowa. Canadian Field-Naturalist 74: 58.

Cody, W. J. 1963. Index Seminum. Agriculture Canada, Plant Research Institute. 40 pages.

Cody, W. J. 1964. Index Seminum. Agriculture Canada, Plant Research Institute. 38 pages.

Cody, W. J. 1965. Index Seminum. Agriculture Canada, Plant Research Institute. 33 pages.

Cody, W. J. 1966a. Review of T. M. C. Taylor, The lily family (Liliaceae) of British Columbia. Canadian Field-Naturalist 80: 246.

Cody, W. J. 1966b. Review of T. M. C. Taylor, Vascular flora of British Columbia - preliminary check list. Canadian Field-Naturalist 80: 247.

Cody, W. J. 1966c. Index Seminum. Agriculture Canada, Plant Research Institute. 21 pages.

Cody, W. J. 1967a. Review of R. H. Mohlenbrock, The illustrated flora of Illinois: ferns. Canadian Field-Naturalist 81: 296-297.

Cody, W. J. 1967b. Index Seminum. Agriculture Canada, Plant Research Institute. 21 pages.

Cody, W. J. 1967c. Review of F. H. Montgomery, Plants from sea to sea. Economic Botany 21: 196.

Cody, W. J. 1968a. Review of R. G. H. Cormack, Wild flowers of Alberta. Canadian Field-Naturalist 82: 300.

Cody, W. J. 1968b. Review of W. G. Hardy, Alberta - A natural history. Greenhouse-Garden-Grass 7: 22.

Cody, W. J. 1968c. Index Seminum. Agriculture Canada, Plant Research Institute. 22 pages.

Cody, W. J. 1969a. Review of A. Feininger, Trees. Canadian Field-Naturalist 83: 71.

Cody, W. J. 1969b. Review of D. Archibald et al., Quick-key guide to wildflowers of northeastern and central United States and adjacent Canada. Canadian Field-Naturalist 83: 179.

Cody, W. J. 1969c. Review of J. S. Maini and J. B. Cayford (editors), Growth and utilization of poplars in Canada. Canadian Field-Naturalist 83: 288-289.

Cody, W. J. 1969d. Review of E. Hultén, Flora of Alaska and neighboring territories: a manual of the vascular plants. Canadian Field-Naturalist 83: 412-413.

Cody, W. J. 1969e. Review of A. E. Radford et al., Manual of the vascular flora of the Carolinas. Canadian FieldNaturalist 83: 417.

Cody, W. J. 1969f. Review of C. F. Brockman, Trees of North America: a field guide to the major native and introduced species north of Mexico. Canadian Field-Naturalist 83: 419.

Cody, W. J. 1969g. Index Seminum. Agriculture Canada, Plant Research Institute. 28 pages.

Cody, W. J. 1970a. Review of F. Marie-Victorin and F. Rolland-Germain, Flore de l'Anticosti-Minganie. Canadian Field-Naturalist 84: 72.

Cody, W. J. 1970b. Review of C. L. Hitchcock et al., Vascular plants of the Pacific Northwest, Part I: vascular cryptograms, gymnosperms and monocotyledons. Canadian FieldNaturalist 84: 200.

Cody, W. J. 1970c. Review of W. G. Stewart and L. E. James, A guide to the flora of Elgin County, Ontario. Canadian Field-Naturalist 84: 327.

Cody, W. J. 1970d. Index Seminum. Agriculture Canada, Plant Research Institute. 24 pages.
Cody, W. J. 1971a. Review of T. M. C. Taylor, Pacific Northwest ferns and their allies. Canadian Field-Naturalist 85: 83.

Cody, W. J. 1971b. Review of R. A. Nelson, Handbook of Rocky Mountain plants. Canadian Field-Naturalist 85: 196.

Cody, W. J. 1971c. Review of R. J. Preston Jr., Rocky Mountain trees. Canadian Field-Naturalist 85: 346.

Cody, W. J. 1971d. Review of H. L. Keeler, Our northern shrubs and how to identify them. Canadian Field-Naturalist 85: 346-347.

Cody, W. J. 1971e. Index Seminum. Agriculture Canada, Plant Research Institute. 24 pages.

Cody, W. J. 1972a. Review of J. Mirsky, To the Arctic! The story of northern explorers from earliest times to the present. Canadian Field-Naturalist 86: 108.

Cody, W. J. 1972b. Review of A. W. Taylor, Wild flowers of the Pyrenees. Canadian Field-Naturalist 86: 411-412.

Cody, W. J. 1972c. Index Seminum. Agriculture Canada, Plant Research Institute. 36 pages.

Cody, W. J. 1973a. Review of W. A. Weber, Rocky Mountain flora, fourth edition. Canadian Field-Naturalist 87: 194.

Cody, W. J. 1973b. Review of A. Cronquist et al., Intermountain flora: vascular plants of the Intermountain West, U.S.A. Volume 1. Geological and botanical history of the region, its plant geography and a glossary, the vascular cryptograms and the gymnosperms. Canadian FieldNaturalist 87: 329-330.

Cody, W. J. 1973c. Review of E. G. Voss, Michigan flora: a guide to the identification and occurrence of the native and naturalized seed-plants of the state. Part I. Gymnosperms and monocots. Canadian Field-Naturalist 87: 330.

Cody, W. J. 1973d. Review of C. L. Hitchcock and A. Cronquist, Flora of the Pacific Northwest - an illustrated manual. Canadian Field-Naturalist 87: 475.

Cody, W. J. 1973e. Index Seminum. Agriculture Canada, Plant Research Institute. 37 pages.

Cody, W. J. 1974a. Review of R. H. Mohlenbrock and J. Voigt, A flora of southern Illinois. Canadian Field-Naturalist 88: 531.

Cody, W. J. 1974b. Review of J. Jalas and J. Suominen, Atlas Florae Europaeae: distribution of vascular plants in Europe. Canadian Field-Naturalist 88: 533-534.

Cody, W. J. 1974c. Review of The milepost-All-the-North travel guide (Alaska-The Yukon-Northern British ColumbiaNorthwest Territories). Canadian Field-Naturalist 88: 546.

Cody, W. J. 1974d. Review of Z. Zuccoli, Flora arctica. Economic Botany 28: 413, 448.

Cody, W. J. 1975a. Review of C. Rousseau, Géographie floristique du Québec/Labrador. Distribution des principales espèces vasculaires. Canadian Field-Naturalist 89: 198.

Cody, W. J. 1975b. Review of S. Osborn (editor), The discovery of the Northwest Passage by H.M.S. "Investigator", Captain R. M'Clure 1850, 1851, 1852, 1853, 1854, and C. F. Hall, Life with the Esquimaux, a narrative of arctic experience in search of survivors of Sir John Franklin's expedition. Canadian Field-Naturalist 89: 203-204.

Cody, W. J. 1975c. Review of H. A. Stephens, Woody plants of the north central plains. Canadian Field-Naturalist 89: 95.

Cody, W. J. 1975d. Review of H. A. White and M. Williams, The Alaska-Yukon wild flowers guide. Canadian FieldNaturalist 89: 339. 
Cody, W. J. 1976a. Review of R. T. Clausen, Sedum of North America north of the Mexican Plateau. Canadian FieldNaturalist 90: 210-211.

Cody, W. J. 1976b. Review of Flore du Canada. Canadian Field-Naturalist 90: 211.

Cody, W. J. 1977a. Review of A. Potvin, A panorama of Canadian forests. Canadian Field-Naturalist 91: 206.

Cody, W. J. 1977b. Review of M. Ferguson and R. M. Saunders, Canadian wildflowers. Canadian Field-Naturalist 91: 206.

Cody, W. J. 1977c. Review of W. A. Weber, Rocky Mountain flora, fifth edition. Canadian Field-Naturalist 91: 207.

Cody, W. J. 1977d. Review of R. H. Mohlenbrock, Guide to the vascular flora of Illinois. Canadian Field-Naturalist 91: 207.

Cody, W. J. 1977e. Review of F. R. Vance et al., Wildflowers across the Prairies. Canadian Field-Naturalist 91: 334.

Cody, W. J. 1977f. Review of N. C. Fassett, Spring flora of Wisconsin. Canadian Field-Naturalist 91: 334.

Cody, W. J. 1978a. Review of T. Van Bruggen, The vascular plants of South Dakota. Canadian Field-Naturalist 92: 102.

Cody, W. J. 1978b. Review of R. L. Taylor and B. MacBryde, Vascular plants of British Columbia -A descriptive resource inventory. Canadian Field-Naturalist 92: 103-104.

Cody, W. J. 1978c. Review of A. Cronquist et al., Intermountain flora: vascular plants of the Intermountain West, U.S.A. Volume 6. The monocotyledons. Canadian FieldNaturalist 92: 312-313.

Cody, W. J. 1978d. Review of R. L. McGregor and T. M. Barkley, Atlas of the flora of the Great Plains. Canadian Field-Naturalist 92: 313.

Cody, W. J. 1978e. Review of J. H. Hudson, Carex in Saskatchewan. Canadian Field-Naturalist 92: 414.

Cody, W. J. 1979a. Review of R. D. Dorn, Manual of the vascular plants of Wyoming. Canadian Field-Naturalist 93: 211.

Cody, W. J. 1979b. Review of S. G. Shetler and L. E. Skog, A provisional checklist of species for Flora North America (Revised). Canadian Field-Naturalist 93: 212.

Cody, W. J. 1979c. Review of J. P. Smith Jr., Vascular plant families. Canadian Field-Naturalist 93: 457.

Cody, W. J. 1980a. Review of L. C. Linn, Eastern North America's wildflowers. Canadian Field-Naturalist 94: 102.

Cody, W. J. 1980b. Review of V. Ahmadjian, Flowering plants of Massachusetts. Canadian Field-Naturalist 94: 210.

Cody, W. J. 1980c. Review of A. J. Petrik-Ott, The pteridophytes of Kansas, Nebraska, South Dakota and North Dakota. Canadian Field-Naturalist 94: 211.

Cody, W. J. 1980d. Review of R. G. Bryan and N. E. Newton-White, Wildflowers of the North. Canadian FieldNaturalist 94: 484.

Cody, W. J. 1980e. Review of J. L. Riley and S. M. McKay, The vegetation and phytogeography of coastal southwestern James Bay. Ontario Field Biologist 34(2): 108.

Cody, W. J. 1981a. Review of A. Cronquist, Vascular flora of the southeastern United States. Volume 1. Asteraceae. Canadian Field-Naturalist 95: 119.

Cody, W. J. 1981b. Review of M. Laird, Bibliography of the natural history of Newfoundland and Labrador. Canadian Field-Naturalist 95: 382.

Cody, W. J. 1981c. Review of R. B. Freeman, British natural history books, 1495-1900: a handlist. Canadian FieldNaturalist 95: 497.

Cody, W. J. 1982. Review of R. W. Becking, Pocket flora of the redwood forest. Canadian Field-Naturalist 96: 501.
Cody, W. J. 1983a. Review of L. Benson, The cacti of the United States and Canada. Canadian Field-Naturalist 97: 137.

Cody, W. J. 1983b. Review of G. W. Douglas et al., The rare vascular plants of the Yukon. Canadian Field-Naturalist 97: 241-242.

Cody, W. J. 1984a. Review of F. C. Seymour, The flora of New England: a manual for the identification of all vascular plants including ferns and fern allies growing without cultivation in New England, second edition. Canadian Field-Naturalist 98: 142.

Cody, W. J. 1984b. Review of J. G. Trelawny, Wildflowers of the Yukon and northwestern Canada including adjacent Alaska. Canadian Field-Naturalist 98: 269.

Cody, W. J. 1984c. Review of Á. Löve, Flora of Iceland. Canadian Field-Naturalist 98: 270.

Cody, W. J. 1984d. Review of M. Ferguson and R. M. Saunders, Canadian wildflowers through the seasons, and $\mathrm{M}$. Ferguson, Canadian wildflowers 1985. Canadian FieldNaturalist 98: 271.

Cody, W. J. 1984e. Review of E. H. Moss, Flora of Alberta, second edition, revised by J. G. Packer. Canadian FieldNaturalist 98: 408-409.

Cody, W. J. 1984f. Review of J. M. Webber, The vascular plant flora of Peel County, Ontario. The Plant Press 2(4): 112-113.

Cody, W. J. 1985a. Review of A. Cronquist et al., Intermountain flora: vascular plants of the Intermountain West, U.S.A. Volume 4. Subclass Asteridae (except Asteraceae). Canadian Field-Naturalist 99: 126-127. 191.

Cody, W. J. 1985b. Review of D. Griffin, Atlantic wildflowers. Canadian Field-Naturalist 99: 556.

Cody, W. J. 1985c. Review of F. R. Vance, J. R. Jowsey, and J. S. McLean, Wildflowers across the prairies, revised and expanded. Canadian Field-Naturalist 99: 557.

Cody, W. J. 1985d. Club Moss. Page 361 in The Canadian Encyclopedia 1. Hurtig, Edmonton.

Cody, W. J. 1985e. Fern. Pages 623-624 in The Canadian Encyclopedia 1. Hurtig, Edmonton.

Cody, W. J. 1985f. Horsetail. Pages 832-833 in The Canadian Encyclopedia 2. Hurtig, Edmonton.

Cody, W. J. 1985g. Porsild, Alf Erling. Page 1456 in The Canadian Encyclopedia 3. Hurtig, Edmonton.

Cody, W. J. 1986a. Review of J. C. Ritchie, Past and present vegetation of the Far Northwest of Canada. Canadian FieldNaturalist 100: 153.

Cody, W. J. 1986b. Review of D. T. MacRoberts, The vascular plants of Louisiana: an annotated checklist and bibliography of the vascular plants reported to grow without cultivation in Louisiana. Canadian Field-Naturalist 100: 304.

Cody, W. J. 1986c. Review of A. Farjon, Pines, drawings and descriptions of the genus Pinus. Canadian Field-Naturalist 100: 305-306.

Cody, W. J. 1986d. Review of I.-C. Chung, The Arctic and the Rockies as seen by a botanist Pictorial. Canadian FieldNaturalist 100: 588.

Cody, W. J. 1987a. Fougère. Page 780 in L'Encyclopédie du Canada 2. Stanké, Montréal.

Cody, W. J. 1987b. Lycopode. Page 1140 in L’Encyclopédie du Canada 2. Stanké, Montréal.

Cody, W. J. 1987c. Porsild, Alf Erling. Page 1557 in L'Encyclopédie du Canada 3. Stanké, Montréal.

Cody, W. J. 1987d. Prêle. Page 1573 in L'Encyclopédie du Canada 3. Stanké, Montréal. 
Cody, W. J. 1987e. Review of T. Van Bruggen, The vascular plants of South Dakota, second edition. Canadian FieldNaturalist 101: 317.

Cody, W. J. 1987f. Review of G. W. Scotter and H. Flygare, Wildflowers of the Canadian Rockies. Canadian FieldNaturalist 101: 318-319.

Cody, W. J. 1987g. Review of A. F. Clewell, Guide to the vascular plants of the Florida Panhandle. Canadian FieldNaturalist 101: 319.

Cody, W. J. 1987h. Review of A. Strid, Mountain flora of Greece, Volume 1. Canadian Field-Naturalist 101: 506.

Cody, W. J. 1987i. Review of Great Plains Flora Association, Flora of the Great Plains. Canadian Field-Naturalist 101: 507-508.

Cody, W. J. 1987j. Review of E. G. Voss, Michigan flora: a guide to the identification and occurrence of the native and naturalized seed plants of the state, Part II: Dicots (Saururaceae - Cornaceae). Canadian Field-Naturalist 101: 650-651.

Cody, W. J. 1988a. Review of E. A. Cope, Native and cultivated conifers of northeastern North America: a guide. Canadian Field-Naturalist 102: 187.

Cody, W. J. 1988b. Review of S. L. Welsh, A Utah flora. Canadian Field-Naturalist 102: 406-407.

Cody, W. J. 1988c. Review of A. R. Clapham, T. G. Tutin, and D. M. Moore, Flora of the British Isles, third edition. Canadian Field-Naturalist 102: 407-408.

Cody, W. J. 1988d. Review of J. Hayward, A new key to wild flowers. Canadian Field-Naturalist 102: 602-603.

Cody, W. J. 1988e. Club Moss. Page 445 in The Canadian Encyclopedia (2nd edition) 1.

Cody, W. J. 1988f. Fern. Pages 758-759 in The Canadian Encyclopedia (2nd edition) 2.

Cody, W. J. 1988g. Horsetail. Pages 1008-1009 in The Canadian Encyclopedia (2nd edition) 2.

Cody, W. J. 1988h. Porsild, Alf Erling. Page 1724 in The Canadian Encyclopedia (2nd edition) 3.

Cody. W. J. 1989a. Review of L. Couillard et al., The rare plants of the Mingan Archipelago. Canadian Field-Naturalist 103: 126.

Cody, W. J. 1989b. Review of W. A. Weber, Colorado flora: Western Slope. Canadian Field-Naturalist 103: 126-127.

Cody, W. J. 1989c. Review of J. C. Ritchie, Postglacial vegetation of Canada. Canadian Field-Naturalist 103: 463.

Cody, W. J. 1989d. Review of B. J. Albee et al., Atlas of the vascular plants of Utah. Canadian Field-Naturalist 103: 463-464.

Cody, W. J. 1989e. Review of A. Johnson, Plants and the Blackfoot. Canadian Field-Naturalist 103: 626.

Cody, W. J. 1990a. Review of R. J. Shaw, Vascular plants of northern Utah - an identification manual. Canadian FieldNaturalist 104: 619-620.

Cody, W. J. 1990b. Review of G. W. Douglas et al., The vascular plants of British Columbia. Part I. Gymnosperms and dicotyledons (Aceraceae through Curcurbitaceae). Canadian Field-Naturalist 104: 620.

Cody, W. J. 1991a. Review of R. C. Barneby, Fabales. Volume 3, Part B of A. Cronquist et al., Intermountain flora: vascular plants of the Intermountain West, U.S.A. Canadian Field-Naturalist 105: 144.

Cody, W. J. 1991b. Review of I.-C. Chung, Eastern North America as seen by a botanist: Pictorial I, the Arctic Region; and Pictorial II, the Wooded Regions. Canadian Field-Naturalist 105: 144.
Cody, W. J. 1991c. Review of T. C. Brayshaw, Buttercups, waterlilies, and their relatives: (the order Ranales) in British Columbia. Canadian Field-Naturalist 105: 302.

Cody, W. J. 1992a. Review of J. T. Schofield, Discovering wild plants, Alaska, western Canada, and the Northwest. Canadian Field-Naturalist 106: 167.

Cody, W. J. 1992b. Review of T. C. Peattie, A natural history of trees of eastern and central North America, and T. C. Peattie, A natural history of western trees. Canadian FieldNaturalist 106: 415-416.

Cody, W. J. 1992c. Review of D. Isely, Vascular flora of the southeastern United States. Volume 3, Part 2. Leguminosae (Fabaceae). Canadian Field-Naturalist 106: 416.

Cody, W. J. 1992d. Review of G. B. Ownbey and T. Morley, Vascular plants of Minnesota, a checklist and atlas. Canadian Field-Naturalist 106: 417.

Cody, W. J. 1992e. Review of C. Jermy and J. Camus, The illustrated field guide to ferns and allied plants of the British Isles. Canadian Field-Naturalist 106: 417.

Cody, W. J. 1992f. Review of H. A. Gleason and A. Cronquist, Manual of vascular plants of northeastern United States and adjacent Canada. Canadian Field-Naturalist 106: 417-418.

Cody, W. J. 1993a. Review of W. A. Weber and R. C. Wittmann, Catalogue of the Colorado flora: a biodiversity baseline. Canadian Field-Naturalist 107: 131.

Cody, W. J. 1993b. Review of A. MacKinnon, J. Pojar, and R. Coupé (editors), Plants of northern British Columbia. Canadian Field-Naturalist 107: 131-132.

Cody, W. J. 1994a. Review of R. D. Dorn, Vascular plants of Wyoming, second edition. Canadian Field-Naturalist 108: 125.

Cody, W. J. 1994b. Review of J. J. Schofield, Alaska's wild plants: a guide to Alaska's edible harvest. Canadian FieldNaturalist 108: 126.

Cody, W. J. 1994c. Review of J. De Santo, Bitterroot. Canadian Field-Naturalist 108: 126.

Cody, W. J. 1994d. Review of J. C. Hickman (editor), The Jepson manual: higher plants of California. Canadian Field-Naturalist 108: 128.

Cody, W. J. 1994e. Review of E. C. Pielou, A naturalist's guide to the Arctic. Canadian Field-Naturalist 108: 513.

Cody, W. J. 1994f. Review of A. Cronquist, Intermountain flora: vascular plants of the Intermountain West, U.S.A. Volume 5. Asterales. Canadian Field-Naturalist 108: 513514.

Cody, W. J. 1994g. Review of S. L. Welsh et al., A Utah flora. Canadian Field-Naturalist 108: 514.

Cody, W. J. 1995a. Review of K. Budd and R. Careless (editors), Tatshenshini River wild. Canadian Field-Naturalist 109: 139-140.

Cody, W. J. 1995b. Horsetail. In The Canadian Encyclopedia, updated CD-ROM.

Cody, W. J. 1995c. Club-moss. In The Canadian Encyclopedia, updated CD-ROM.

Cody, W. J. 1995d. Fern. In the Canadian Encyclopedia, updated CD-ROM.

Cody, W. J. 1995e. Review of Flora of North America Editorial Committee, Flora of North America north of Mexico. Volume 1. Introduction. Canadian Field-Naturalist 109: 387-389.

Cody, W. J. 1995f. Review of Flora of North America Editorial Committee, Flora of North America north of Mexico. Volume 2. Pteridophytes and gymnosperms. Canadian Field-Naturalist 109: 390. 
Cody, W. J. 1995g. Review of W. B. Zomlefer, A guide to flowering plant families. Canadian Field-Naturalist 109: 501-502.

Cody, W. J. 1995h. Review of L. Brako et al., Scientific and common names of 7000 vascular plants in the United States. Canadian Field-Naturalist 109: 504.

Cody, W. J. 1996a. Review of G. W. Douglas, The sunflower family (Asteraceae) of British Columbia. Volume 2. Astereae, Anthemideae, Eupatorieae and Inuleae. Canadian Field-Naturalist 110: 565.

Cody, W. J. 1996b. Review of Bruce-Grey Plant Committee, A checklist of vascular plants for Bruce and Grey Counties. Canadian Field-Naturalist 110: 721.

Cody, W. J. 1996c. Review of R. M. Turner et al., Sonoran Desert plants: an ecological atlas. Canadian Field-Naturalist 110: 721.

Cody, W. J. 1997. Review of D. Johnson et al., Plants of the western boreal forest and aspen parkland. Canadian FieldNaturalist 111: 697-698.

Cody, W. J. 1998a. Review of A. Crowder et al., Plants of the Kingston region. Canadian Field-Naturalist 112: 179.

Cody, W. J. 1998b. Review of R. W. Scott, The alpine flora of the Rocky Mountains. Volume 1. The Middle Rockies. Canadian Field-Naturalist 112: 182-183.

Cody, W. J. 1998c. Review of A. Cronquist et al., Intermountain flora: vascular plants of the Intermountain West, U.S.A. Volume 3, Part A. Subclass Rosidae (except Fabales). Canadian Field-Naturalist 112: 183.

Cody, W. J. 1998d. Review of A. F. Tryon and R. C. Moran, The ferns and allied plants of New England. Canadian Field-Naturalist 112: 568.

Cody, W. J. 1998e. Review of R. S. Mitchell and G. C. Tucker, Revised checklist of New York State plants. Canadian Field-Naturalist 112: 568-569.

Cody, W. J. 1998f. Review of B. Hallworth and C. C. Chinnappa, Plants of Kananaskis Country in the Rocky Mountains of Alberta. Canadian Field-Naturalist 112: 570-571.

Cody, W. J. 1998g. Review of N. H. Holmgren, Illustrated companion to Gleason and Cronquist's Manual: illustrations of the vascular plants of northeastern United States and adjacent Canada. Canadian Field-Naturalist 112: 748.

Cody, W. J. 1999a. Review of R. P. Wunderlin, Guide to the vascular plants of Florida. Canadian Field-Naturalist 113: 547.

Cody, W. J. 1999b. Review of S. G. Newmaster et al., Ontario plant list. Canadian Field-Naturalist 113: 703.

Cody, W. J. 1999c. Review of H. Qian and K. Klinka, Plants of British Columbia, scientific and common names of vascular plants, bryophytes and lichens. Canadian FieldNaturalist 113: 704.

Cody, W. J. 1999e. Review of A. Haines and T. F. Vining, Flora of Maine: a manual for identification of native and naturalized vascular plants of Maine. Canadian FieldNaturalist 113: 704-705.

Cody, W. J. 1999e. Review of G. W. Douglas et al., Rare native plants of British Columbia. Canadian Field-Naturalist 113: 706.

Cody, W. J. 2000a. Review of G. M. Diggs Jr. et al., Shinners \& Mahler's Illustrated flora of north central Texas. Canadian Field-Naturalist 114: 170.

Cody, W. J. 2000b. Review of R. K. Rabeler, Gleason's Plants of Michigan: a field guide. Canadian Field-Naturalist 114: 171 .
Cody, W. J. 2000c. Review of the Bruce-Grey Plant Committee, A guide to the ferns of Grey and Bruce Counties, Ontario. Canadian Field-Naturalist 114: 345.

Cody, W. J. 2000d. Review of S. S. Talbot et al., Atlas of endemic vascular plants of the Arctic. Canadian FieldNaturalist 114: 720-721.

Cody, W. J. 2000e. Review of G. A. Petrides, Trees of the Pacific Northwest. Canadian Field-Naturalist 114: 721.

Cody, W. J. 2001a. Review of H. R. Hinds, Flora of New Brunswick, second edition. Canadian Field-Naturalist 115: 718.

Cody, W. J. 2001b. Review of R. P. Wunderlin and B. F. Hansen, Flora of Florida. Volume 1. Pteridophytes and gymnosperms. Canadian Field-Naturalist 115: 718-719.

Cody, W. J. 2001c. Review of D. Bick, Flora of Mount Rainier National Park. Canadian Field-Naturalist 115: 720.

Cody, W. J. 2001d. Review of J. K. Morton and J. M. Venn, The Flora of Manitoulan [sic] Island and the adjacent islands of Lake Huron, Georgian Bay and the North Channel, third edition. Canadian Field-Naturalist 115: 721.

Cody, W. J. 2002a. Review of D. G. Frodin, Guide to standard floras of the world: an annotated geographically arranged systematic bibliography of the principal floras, enumerations, checklists, and chorological atlases of different areas, second edition. Canadian Field-Naturalist 116: 168.

Cody, W. J. 2002b. Review of L. Kershaw et al., Rare vascular plants of Alberta. Canadian Field-Naturalist 116: 344345.

Cody, W. J. 2002c. Review of G. W. Douglas, D. Meidinger, and J. L. Penny, Rare native vascular plants of British Columbia, second edition. Canadian Field-Naturalist 116: 670.

Cody, W. J. 2002d. Review of G. Lamoureux and R. Larose, Flore printanière. Canadian Field-Naturalist 116: 670-671.

Cody, W. J. 2003a. Review of G. W. Douglas et al., Illustrated flora of British Columbia, Volumes 1-8. Canadian Field-Naturalist 117: 329.

Cody, W. J. 2003b. Review of L. Kershaw, Ontario wild flowers. Canadian Field-Naturalist 117: 330.

Cody, W. J. 2003c. Review of D. More and J. White, The illustrated encyclopedia of trees. Canadian Field-Naturalist 117: 496.

Cody, W. J. 2003d. Review of D. E. Schnell, Carnivorous plants of the United States and Canada, second edition. Canadian Field-Naturalist 117: 496-497.

Cody, W. J. 2003e. Review of J. L. Riley, Flora of the Hudson Bay Lowland and its postglacial origins. Canadian Field-Naturalist 117: 669-670.

Cody, W. J. 2004a. Review of H. A. Gleason and A. Cronquist, Manual of vascular plants of northeastern United States and adjacent Canada, second edition. Canadian Field-Naturalist 118: 147.

Cody, W. J. 2004b. Review of J. G. Trelawny, Wild flowers of the Yukon, Alaska and northwestern Canada, 2nd edition. Canadian Field-Naturalist 118: 289.

Cody, W. J. 2004c. Review of L. J. Clark, Wild flowers of field \& slope in the Pacific Northwest, Wild flowers of forest \& woodland in the Pacific Northwest, and Wild flowers of the mountains in the Pacific Northwest. Canadian FieldNaturalist 118: 289. Re-issued. Canadian Field-Naturalist 118: 476. 
Cody, W. J. 2004d. Review of L. W. Clark, edited by J. G. Trelawny, Lewis Clark's field guide to wildflowers of the sea coast in the Pacific Northwest. Canadian Field-Naturalist 118: 476.
Cody, W. J. 2005a. Review of M. Blondeau, C. Roy, and A. Cuerrier, Atlas des plantes des villages du Nunavik. - Atlas of the plants of the Nunavik villages. Canadian Field-Naturalist 119: 150 .

Cody, W. J. 2005b. Review of D. Ames et al., Orchids of Manitoba. Canadian Field-Naturalist 119: 463.

\section{Appendix Table 3. New taxa and new combinations published by W. J. Cody with reference, including taxa described or transferred by other botanists in Bill's papers. Specimen citations are included for the new names. All holotypes are at DAO.}

Adiantum pedatum L. ssp. calderi Cody, Rhodora 85: 93-94. 1983. CANADA: Quebec, Gaspé Co., Mt. Albert, Collins \& Fernald s.n., 14 August 1905.

Androsace chamaejasme Host var. lehmanniana (Sprengel) Boivin in Cody, Canadian Field-Naturalist 68(3): 116. 1954.

Antennaria leontopodioides Cody, Canadian FieldNaturalist 70: 127. 1957. CANADA: District of Mackenzie, Indin Lake, $64^{\circ} 17^{\prime} \mathrm{N}, 115^{\circ} 12^{\prime} \mathrm{W}, \operatorname{Cody}$ \& McCanse 3473, 12 August 1949.

Aster nahanniensis Cody in Scotter \& Cody, Le Naturaliste canadien 101: 888. 1974. CANADA: District of Mackenzie, South Nahanni River area, $61^{\circ} 31^{\prime} 30^{\prime \prime} \mathrm{N}, 126^{\circ} 29^{\prime} \mathrm{W}$, G. W. Scotter 17412, 16 September 1971.

Aster sibiricus L. var. pygmaeus (Lindley) Cody, Canadian Field-Naturalist 68(3): 117. 1954.

Botrychium virginianum (L.) Sw. var. europaeum Angstrom f. heterodoxum Cody, American Fern Journal 51: 36. 1961. CANADA: Saskatchewan, McKague, A.J. Breitung s.n., 25 June 1935.

Botrychium virginianum (L.) Sw. var. virginianum f. anomalum Cody, American Fern Journal 51: 36. 1961. CANADA: Ontario, Renfrew Co., $21 \frac{1}{2}$ miles west of Braeside, Cody \& Dore 11133, 19 June 1959.

Braya glabella Richardson ssp. purpurascens (R. Brown) Cody, Canadian Field-Naturalist 108(1): 93. 1994.

Cardamine oligosperma Nutt. ssp. kamtschatica (Regel) Cody, Canadian Field-Naturalist 108(1): 93. 1994.

Cardamine purpurea Cham. \& Schlecht. f. albiflora (Hultén) Cody, Canadian Field-Naturalist 108(1): 93. 1994.

Dryopteris disjuncta (Ledeb.) C.V. Morton f. glandulosa (Tryon) Cody, American Fern Journal 45: 126. 1955.

Elymus trachycaulus (Link) Gould ex Shiners ssp. glaucus (Pease \& A.H. Moore) Cody, Canadian Field-Naturalist 108(1): 93. 1994.

Gentianella amarella (L.) Börner ssp. acuta (Michx.) J. M. Gillett f. albescens (Lepage) Cody, Canadian Field-Naturalist 108(1): 94. 1994.

Haplopappus lanceolatus (Hook.) T.\& G. var. sublanatus Cody, Canadian Field.-Naturalist 70: 126.
1957. CANADA: District of Mackenzie, salt plain $\mathrm{W}$ of Fort Smith, $60^{\circ} 03^{\prime} \mathrm{N} 112^{\circ} 25^{\prime} \mathrm{W}$, Cody \& Loan 4576, 20 July 1950.

Hedysarum alpinum L. f. albiflorum (Standley) Cody, Canadian Field-Naturalist 108(1): 94. 1994.

Hedysarum boreale Nutt. subsp. mackenziei (Richards.) Welsh f. niveum (Boivin) Cody, Canadian Field-Naturalist 108(1): 94. 1994.

Lagotis glauca Gaertn. ssp. minor (Willd.) Hultén f. albiflora Cody, Canadian Field-Naturalist 108: 94. 1994. CANADA: Yukon, Ogilvie Mountains, 7 miles South of Tombstone Mountain, $64^{\circ} 18^{\prime} \mathrm{N}, 138^{\circ} 38^{\prime} \mathrm{W}$, Cody \& Ginns 34664, 16 July 1984.

Lilium canadense L. ssp. michiganense (Farwell) B. Boivin \& Cody, Rhodora 58(685): 17. 1956.

Lilium canadense L. ssp. michiganense (Farwell) B. Boivin \& Cody f. peramoenum (Farwell) B. Boivin \& Cody, Rhodora 58(685): 18. 1956.

Lilium canadense L. ssp. michiganense (Farwell) B. Boivin \& Cody f. uniflorum (Farwell) B. Boivin \& Cody, Rhodora 58(685): 18. 1956.

Lilium canadense L. ssp. superbum (L.) B. Boivin \& Cody, Rhodora 58(685): 19. 1956.

Lupinus arcticus S. Wats. f. albus Cody, Canadian Field-Naturalist 108(1): 94. 1994. CANADA: Yukon Territory, Richardson Mountains, S end of Skull Range, $68^{\circ} 28^{\prime} \mathrm{N}, 137^{\circ} 27^{\prime} \mathrm{W}$, Cody \& Ginns 31629 , 12 July 1982.

Lychnis apetala L. var. arctica (Fries) Cody, Canadian Field-Naturalist 67(1): 41. 1953.

Lychnis apetala L. var. arctica (Fries) Cody f. palea (Pal.) Cody, Canadian Field-Naturalist 67(1): 41. 1953.

Myosotis alpestris F.W. Schmidt ssp. asiatica Vestergr. ex Hultén f. eyerdamii (B. Boivin) Cody, Canadian Field-Naturalist 108(1): 94. 1994.

Nasturtium crystallinum (Rollins) G. Mulligan in G. A. Mulligan \& W. J. Cody, Canadian Field-Naturalist 109(1): 111. 1995.

Oxytropis campestris (L.) DC. ssp. roaldii (Ostenf.) Cody, Canadian Field-Naturalist 108(1): 94. 1994.

Oxytropis campestris (L.) DC. ssp. varians (Rydb.) Cody, Canadian Field-Naturalist 108(1): 94. 1994.

Oxytropis deflexa (Pall.) DC. ssp. foliolosa (Hook.) Cody, Canadian Field-Naturalist 108(1): 94. 1994. 
Oxytropis deflexa (Pall.) DC. ssp. sericea (T. \& G.) Cody, Canadian Field-Naturalist 108(1): 94. 1994.

Oxytropis nigrescens (Pall.) Fisch. ssp. lonchopoda (Barneby) Cody, Canadian Field-Naturalist 108(1): 94. 1994.

Oxytropis sericea Nutt. ssp. spicata (Hook.) Cody, Canadian Field-Naturalist 108(1): 94. 1994.

Parrya arctica R.Br. f. albiflora Boivin in Cody, Canadian Field-Naturalist 67: 42. 1953. CANADA: District of Franklin, Cambridge Bay, Sweatman \& Smith 6, 2 July 1950.

Parrya nudicaulis (L.) Regel f. albiflora Cody, Canadian Field-Naturalist 108(1): 94. 1994. CANADA: Yukon Territory, hills 15 miles $\mathrm{S}$ of Dawson, $63^{\circ} 55^{\prime} \mathrm{N}, 139^{\circ} 28^{\prime} \mathrm{W}$, elevation 3800', Cody \& Ginns 33444, 5 July 1984.

Pedicularis lanata Cham. \& Schlecht. f. alba Cody, Canadian Field-Naturalist 65(4): 143. 1951. CANADA: District of Keewatin, Southampton Island near Kirchoffer R., W. J. Cody 1146, 3 July 1948.

Pedicularis sudetica Willd. f. alba Cody, Canadian Field-Naturalist 65(4): 143. 1951. CANADA: District of Keewatin, Southampton Island, Coral Harbour, W. J. Cody 1352A, 16 July 1948.

Pellaea glabella Mett. ex Kuhn var. nana (Richardson) Cody, Canadian Field-Naturalist 77(2) 109. 1963.

Petasites frigidus (L.) Fr. ssp. arcticus (Porsild) Cody, Canadian Field-Naturalist 108(1): 94. 1994.

Petasites frigidus (L.) Fr. ssp. nivalis (Greene) Cody, Canadian Field-Naturalist 108(1): 94. 1994.

Petasites frigidus (L.) Fr. ssp. palmatus (Aiton) Cody, Canadian Field-Naturalist 108(1): 94. 1994.

Polemonium boreale Adams f. albiflorum Cody, Canadian Field-Naturalist 117: 462. 2003. CANADA: Mackenzie, Horton River, 69² $42^{\prime} \mathrm{N}, 126^{\circ} 56^{\prime} \mathrm{W}, G$. W. Scotter 10101b, 6 July 1995.
Polystichum $\times$ hagenahii Cody, American Fern Journal 58: 30. 1968. CANADA: Ontario, Bruce Co., Cape Crocker Indian Reservation, Wagner \& Hagenah s.n., 1953.

Primula borealis Duby f. albiflora Cody, Canadian Field-Naturalist 79: 105. 1965. CANADA: District of Mackenzie, Anderson River Delta, 69 $42^{\prime} \mathrm{N}$, 12900'W, T. W. Barry 290, 27 June 1962.

Saussurea angustifolia (Willd.) DC. ssp. yukonesnis (Porsild) Cody, Canadian Field-Naturalist 108(1): 95. 1994.

Saxifraga bronchialis L. ssp. codyana (Zhmylev) Cody, Canadian Field-Naturalist 108(1): 94. 1994.

Saxifraga tricuspidata Rottb. f. woodruffii Calder in Cody, Canadian Field-Naturalist 64: 92. 1950. CANADA: District of Franklin, Melville Peninsula, Committee Bay, Woodruff 38, 20 August 1948.

Silene acaulis L. ssp. subacaulescens (F.N. Williams) Hultén f. albiflora Cody, Canadian Field-Naturalist 108(1): 94. 1994. CANADA: Yukon Territory, km 21, Upper Sheep Creek Rd. off km 154 Canol Rd., elevation 5800', Hodgson 1421A, 27 July 1984.

Silene acaulis L. var. albiflora Cody, Canadian FieldNaturalist 70: 127. 1957 [not there and not found]

Smelowskia borealis (Greene) Drury \& Rollins ssp. jordalii (Drury \& Rollins) Cody, Canadian FieldNaturalist 108(1): 94.

Thalictrum sparsiflorum Turcz. ssp. richardsonii (Gray) Cody, Canadian Field-Naturalist 108(1): 93. 1994.

Veronica wormskjoldii R. \& S. f. albiflora Cody, Canadian Field-Naturalist 108(1): 94. 1994. CANADA: Yukon Territory, Dempster Highway, km 80, G. Brunner s.n., 3 August 1990.

Received February 2010

Accepted 16 May 2010 